\title{
Petrological evolution of silica-undersaturated sapphirine-bearing granulite in the Paleoproterozoic Salvador-Curaçá Belt, Bahia, Brazil
}

\author{
C. de M.M. Leite ${ }^{\mathrm{a}, *}$, J.S.F. Barbosa ${ }^{\text {a }}$, P. Goncalves ${ }^{\mathrm{b}}$, C. Nicollet ${ }^{\mathrm{c}}$, P. Sabaté ${ }^{\mathrm{d}}$ \\ a CPGG - Centro de Geologia e Geofísica/Curso de Pós-Graduação em Geologia da UFBA - Universidade Federal da Bahia, Rua Caetano Moura 123, Federação, 40210-350, \\ Salvador, Bahia, Brazil \\ b UMR 6249, Chrono-environnement-Géosciences, Université de Franche-Comté, 16, Route de Gray, 25030 Besançon, France \\ c Laboratoire Magmas et Volcans-UMR, Université Blaise Pascal, 5, Rue Kessler, 63038 Clermont Ferrand, France \\ d IRD - Institut de Recherche pour le Développement - SHIS OI 11 Conjunto 4 casa 19, Brasília, DF, 71625-240, Brazil
}

\section{A R T I C L E I N F O}

\section{Article history:}

Received 21 December 2007

Received in revised form 17 June 2008

Accepted 24 June 2008

Available online 3 July 2008

\section{Keywords:}

Electron microprobe monazite dating

Paleoproterozoic orogeny

Pseudosections

Retrograde melt-reactions

Ultrahigh-temperature metamorphism

\begin{abstract}
A B S T R A C T
The Salvador-Curaçá Belt, located in São Francisco Craton, Brazil, was subjected to granulite facies metamorphism during the Paleoproterozoic orogeny (c. $2.0 \mathrm{Ga}$ ). Well preserved in enclaves of silicaundersaturated sapphirine-bearing granulite occur in a charnockite outcrop located along a kilometric-scale shear zone. The sapphirine-bearing granulite preserves domains with distinct mineral assemblages that record interactions between melt and peritectic phases (orthopyroxene ${ }_{1}+$ spinel $_{1}+$ biotite $_{1}$ ). Sapphirine was crystallized in the Si-poor cores of the enclaves, sillimanite and spinel-cordierite symplectites in the intermediate Si-rich domains between cores and margins, and garnet and quartz-bearing cordierite/biotite symplectites in Si-rich margins of the enclaves. Melt-rock interactions and metamorphism occurred at ultrahigh temperatures of $900-950{ }^{\circ} \mathrm{C}$ at $7.0-8.0 \mathrm{kbar}$ pressures. The mineralogical evolution of the domains reflects not only the influence of changes in bulk composition in the equilibrium volume of the reactions but also $P-T$ changes during orogeny evolution. Electron microprobe dating of monazite both in the sapphirinebearing granulite and charnockite indicates UHT metamorphism timing at c. 2.08-2.05 Ga that is related to global Paleoproterozoic UHT metamorphic events that occurred during the Columbia supercontinent assembly.

(c) 2008 International Association for Gondwana Research. Published by Elsevier B.V. All rights reserved.
\end{abstract}

\section{Introduction}

Sapphirine-bearing granulite rocks are useful to study the evolution of Earth's continental lithosphere since they contain metamorphic assemblages that might develop as a consequence of ultrahigh-temperature (UHT) conditions (Harley, 1998; Kelsey et al., 2004, 2005; Kelsey, 2008). Microstructures of sapphirine-bearing granulite and the related mineral-forming reactions are attributed to different causes: (a) isochemical metamorphism (e.g. Ellis, 1980; Droop and Bucher-Nurminen, 1984; Hensen, 1986; Harley, 1989; Sengupta et al., 1990; Kriegsman and Schumacher, 1999; Santosh et al., 2007); (b) retrograde melt interactions with peritectic phases (e.g. Hensen and Harley, 1990; Mouri et al., 1996; Kriegsman and Hensen, 1998; Kriegsman, 2001; Moraes et al., 2002; White and Powell, 2002); (c) Si and/or Al-diffusion metasomatism between spinel and melt (Dunkley et al., 1999; Sarkar et al., 2003).

\footnotetext{
* Corresponding author. Present address: PETROBRAS/UN-BA/EXP/SE, Avenida Antônio Carlos Magalhães, 1113 sala 402, Pituba, Salvador, Bahia, 41856-900, Brazil. Fax: +5533483053

E-mail addresses: cmml@ufba.br, cmml@petrobras.com.br (C.M.M. Leite) johildo@cppg.ufba.br (J.S.F. Barbosa), philippe.goncalves@univ-fcomte.fr (P. Goncalves), c.nicollet@opgc.univ-bpclermont.fr (C. Nicollet), pierre.sabate@ird.fr (P. Sabaté).
}

The Salvador-Curaçá Belt (SCB) is a Paleoproterozoic granulite terrain located in the São Francisco Craton, Brazil (Almeida, 1977), that provides a good opportunity to study the process related to the development of sapphirine-bearing assemblages. In the SCB three occurrences of sapphirine-bearing granulites are known (Fujimori and Allard, 1966; Stormer, 1973; Fujimori, 1985; Ackermand et al., 1987; Leite, 2002). The older studies do not present discussions and interpretations which place the sapphirine-bearing mineral assemblages in the context of UHT metamorphism nor do they relate the formation of these assemblages to the tectono-thermal evolution of the SCB. In one of these occurrences the sapphirine-bearing granulite forms enclaves in a charnockite outcrop (Leite, 2002).

Our study focuses on the evolution of the sapphirine-bearing mineral assemblages and discusses the processes and mechanisms for UHT mineral-forming reactions in this occurrence. We investigate the effects of bulk composition as well as the $P-T$ changes on the formation and consumption of $\mathrm{Al}-\mathrm{Mg}$ minerals in the presence of charnockitic magma. The age of the UHT mineral-melt-reactions was also obtained by the $\mathrm{U}-\mathrm{Th}-\mathrm{Pb}$ electron microprobe (EMP) dating of monazite (Montel et al., 1996) and is discussed in the context of the Paleoproterozoic SCB tectonic evolution and in the Columbia supercontinent assembly (Rogers and Santosh, 2002; Zhao et al., 2002, 2004). 


\section{Regional geological setting}

The Salvador-Curaçá Belt (SCB) represents the northern part of the regionally extensive Paleoproterozoic Rhyacian Orogen (Barbosa and Sabaté, 2002, 2004) that evolved during the collision of Archaean blocks at c. 2.0-2.1 Ga (Sabaté et al., 1990; Ledru et al., 1994; Barbosa and Sabaté, 2002, 2004). In the north-eastern region of Bahia State (Fig. 1a), the SCB is juxtaposed to the Archaean Gavião and Serrinha blocks (Fig. 1b).

In the study area (Figs. 1b and 2), the Gavião block has a basement composed of orthogneisses (Melo et al., 1995; Teixeira, 1997) and the Mundo Novo greenstone belt (Mascarenhas and Silva, 1994) with

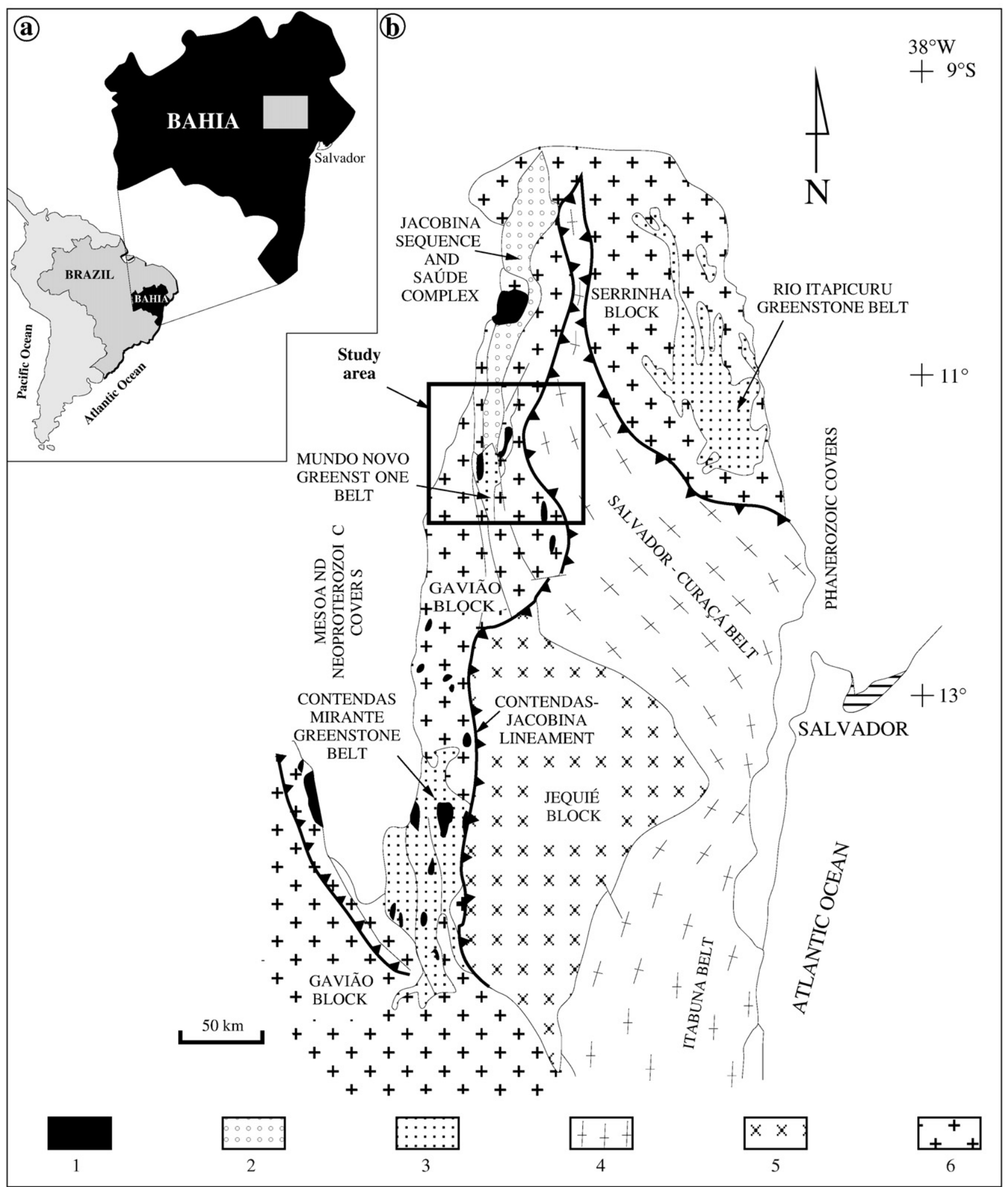

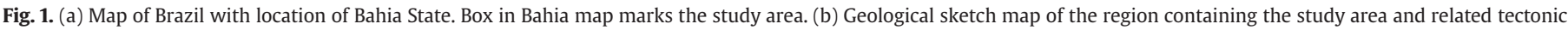

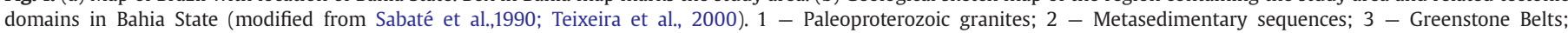
4 - Paleoproterozoic granulite belt; 5 - Archaean granulite cratonic block (Jequié); 6 - Archaean gneissic-migmatitic cratonic blocks (Gavião and Serrinha). 


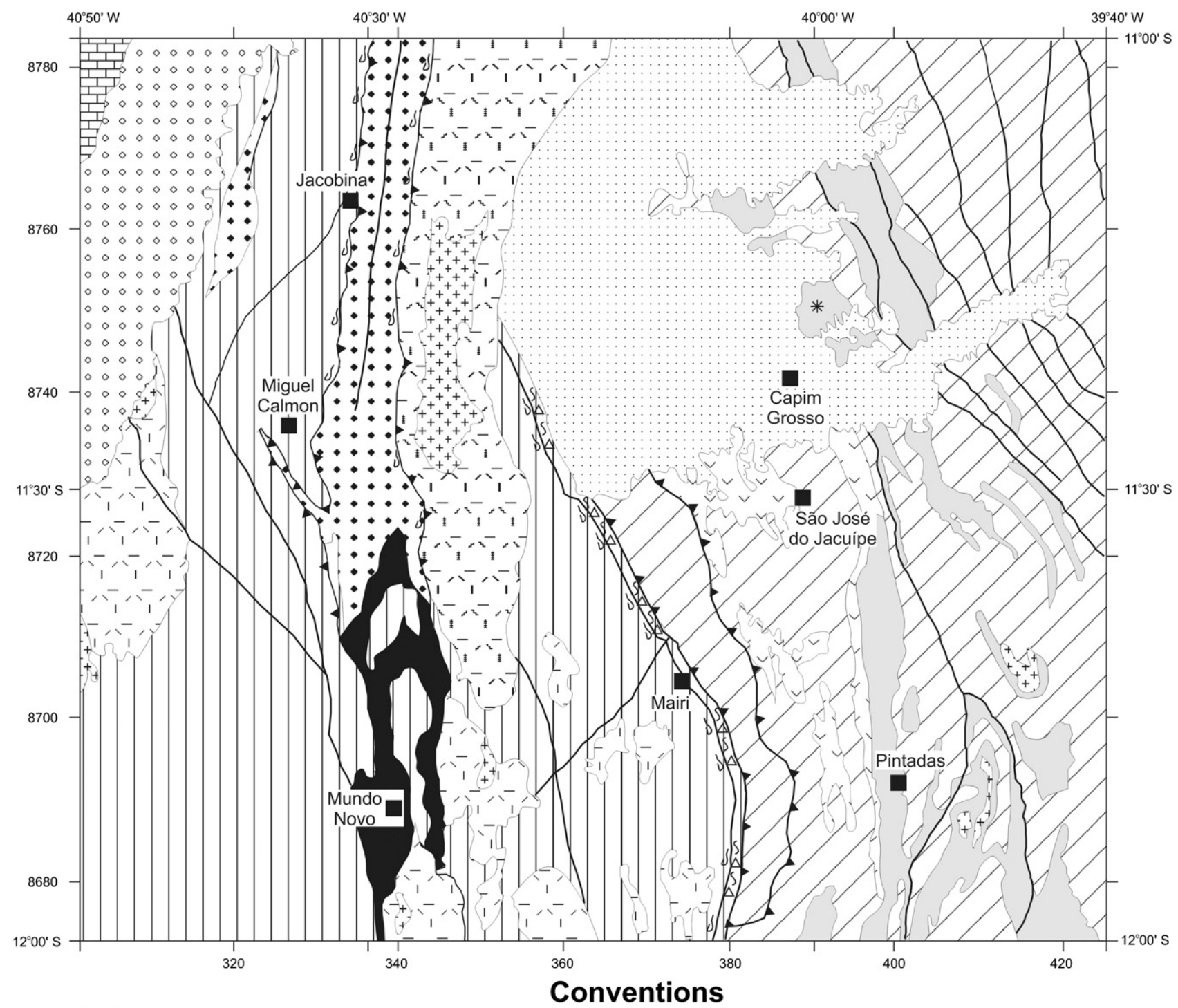

Tertiary and Quaternary covers

Neoproterozoic cover

Mesoproterozoic cover

++
++
++
++
++

\section{SALVADOR-CURAÇÁ BELT}

Tanque Novo - Ipirá Complex

$\checkmark$ Caraíba Complex

$\checkmark$ São José do Jacuípe Suite

GAVIÃO BLOCK

:: Jacobina Sequence

'I' Saúde Complex

Mundo Novo Greenstone Belt

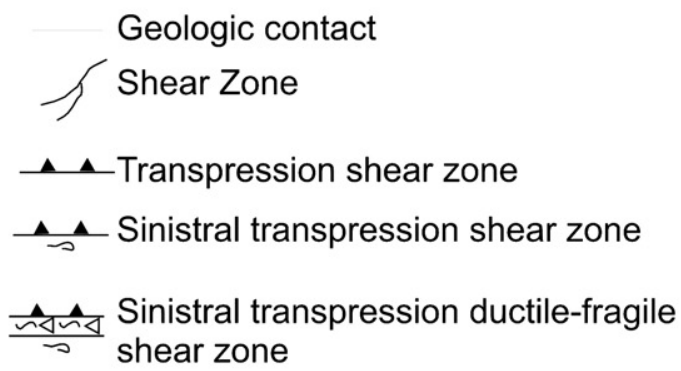

* Sapphirine occurrence

- City

\section{Orthogneisses + granites + amphybolites}

Fig. 2. Geological sketch map of the study area (modified from Melo et al., 1995; Sampaio, 1995; Mascarenhas et al., 1998). 
prevailing metamorphic grade in the amphibolite facies. This basement is dated at c. 3.4-3.2 Ga (Mougeot, 1996; Peucat et al., 2002). Metasedimentary sequences and peraluminous granites cover or intrude this basement (Fig. 2). The metasedimentary sequences constitute the Saúde Complex and the 2.0-1.8 Ga Jacobina foreland basin (Ledru et al., 1997).

The Salvador-Curaçá Belt (SCB) is composed of three lithological units (Fig. 2): (a) the Caraíba Complex, comprising granulites derived from tonalite-trondhjemite-granodiorite protoliths (Teixeira, 1997); (b) the Tanque Novo-Ipirá Complex (Kosin et al., 2003), comprising predominantly leptynitic gneisses and leucogranites together with minor sedimentary derived granulites in the southern part of the study area, or by charnockite-enderbite plutons in the northern part of the area; and (c) the São José do Jacuípe Suite, a gabbro-peridotite granulitic association that probably represents an ophiolitic sequence (Teixeira, 1997).

At least two main episodes of ductile deformation are recorded in the SCB, both contemporaneous with Paleoproterozoic high-grade metamorphism (Sabaté, 1996; Leite, 2002). The first episode $\left(D_{1}\right)$ is characterized by compositional layering and flat-lying foliations $\left(S_{1}\right)$, relict isoclinal folds with approximately $\mathrm{N}-\mathrm{S}$ horizontal axes related to west-verging shear ramps and east-west plunging to the east stretching lineation $\left(L_{1}\right)$. The second episode $\left(D_{2}\right)$ evolved in a transpressional tectonic regime and its deformation geometric pattern is partitioned between a network of NNW-trending folded and steepdipping oblique to strike-slip sinistral shear zone domains. The kinematic indicators ( $\mathrm{S}-\mathrm{C}$ structures, asymmetric foliation trajectories and oblique to subhorizontal $\mathrm{L}_{2}$ stretching lineations) outline tectonic transport from ESE toward WNW.

$\mathrm{U}-\mathrm{Pb}$ SHRIMP ages obtained on tonalitic and enderbitic granulites from the Caraíba Complex show two distinct age populations at ca. 2.7-2.6 Ga and at 2.08-2.07 Ga preserved in cores and rims of zircon respectively (Silva et al., 1997, 2002). The $2.7-2.6$ Ga are interpreted as the age of magmatism in an island-arc setting while the younger 2.08$2.07 \mathrm{Ga}$ age population is related to the high-grade metamorphism (Silva et al., 1997, 2002). Another tonalite from the Caraíba Complex has been dated at $2.1 \mathrm{Ga}$ suggesting that crustal growth in the SCB occurred during the Paleoproterozoic (Carvalho and Oliveira, 2003).

\section{Outcrop description}

The sapphirine-bearing granulite is exposed in the Lajedo farm, $8 \mathrm{~km}$ northeast of Capim Grosso city (Fig. 2) in the Tanque Novo-Ipirá Complex. It occurs as $10-40 \mathrm{~cm}$-wide discontinuous layers and boudins (Fig. 3a, b), within a charnockite pluton in a regional NWSE trending subvertical $D_{2}$ shear zone. Sapphirine is in close spatial association with orthopyroxene and spinel, but sapphirine and spinel only occurring within the internal parts of the layer and boudins where quartz is absent. Sillimanite is restricted to the outer parts of the layer and boudins. Garnet only occurs at the contact between sapphirine-bearing granulite and charnockite where it constitutes spherical zones surrounded by biotite selvages (Fig. 3a).

\section{Petrography}

\subsection{Sapphirine-bearing granulite}

Samples were collected using a portable drill along perpendicular sections across the layer and one of the boudins (Fig. 3a, b). The petrographic analyses demonstrate that the sapphirine-bearing granulite shows both compositional and textural variations from the centre to the margins of the layer and the boudin (Fig. 4a, b). Three distinct domains have been identified based on their petrography and locations across the studied layer and boudin.

Domain I is located in the centres of the layer and boudin. The peak assemblage consists mainly of orthopyroxene $\left(\mathrm{Opx}_{1}, 0.5-18.0 \mathrm{~mm}\right.$
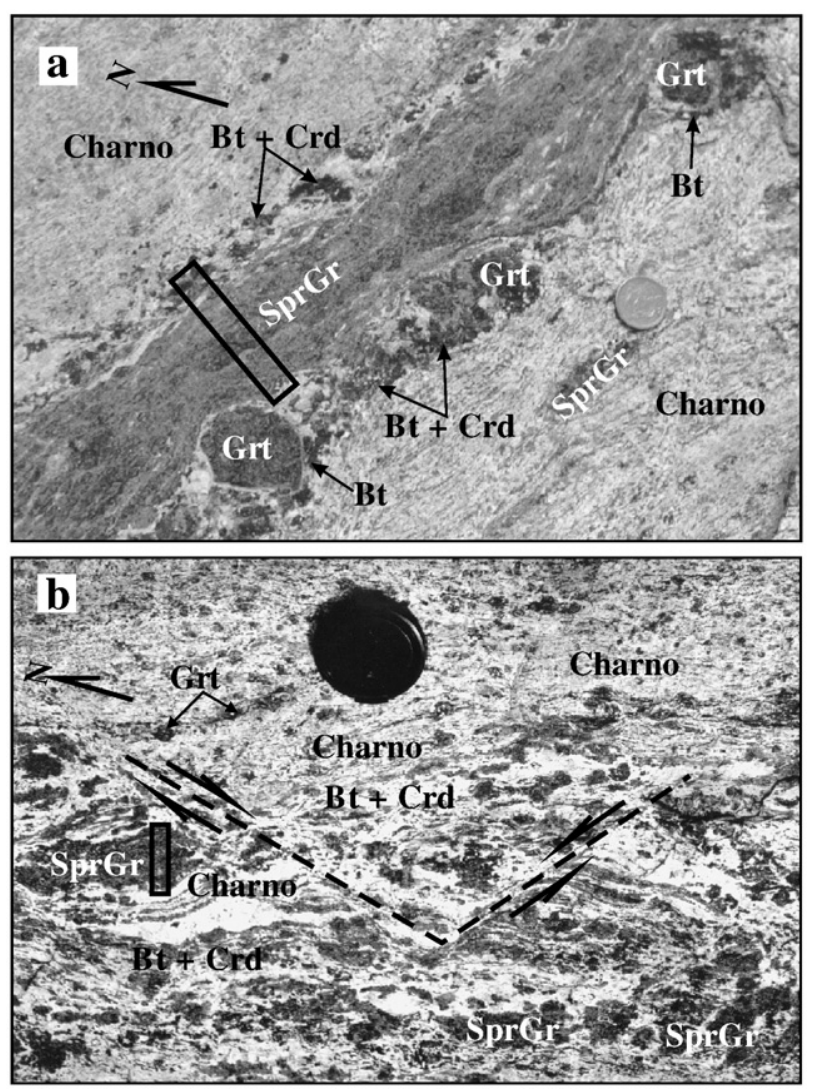

Fig. 3. Outcrop photographs of sapphirine-bearing granulite enclaves in charnockite: (a) Sapphirine-bearing granulite (SprGr) layer in charnockite (Charno) shows garnet (Grt) that occurs as rounded structures and biotite (Bt)+ cordierite ( $\mathrm{Crd}$ ) intergrowths at the contact between sapphirine-bearing granulite and charnockite (diameter of coin is $3.0 \mathrm{~cm}$ ); (b) Conjugate shear bands forming pinch and swell structures in sapphirinebearing granulite (SprGr) with inflow of charnockite (Charno) (diameter of lens cap is $6.0 \mathrm{~cm}$ ). Rectangles on the photos indicate the sampling points and the location of the sketches presented in Fig. 4a and b.

long), sapphirine ( $\mathrm{Spr}_{1}, 0.3-2.5 \mathrm{~mm}$ long) and biotite $\left(\mathrm{Bt}_{1}, 0.5-8.0 \mathrm{~mm}\right.$ long) porphyroblasts in the layer (sample 155, Table 1; Fig. 4a) and in the boudin (sample 155B, Table 1; Fig. 4b). Spinel occurs as inclusions $\left(\mathrm{Spl}_{1 \mathrm{i}}\right)$ in xenomorphic sapphirine grains only in the layer (Figs. 4a, 5a). When sapphirine occurs as sub-euhedral porphyroblasts with straight contacts with orthopyroxene, sapphirine is free of spinel inclusions (Figs. 4a, 5b). Biotite also occurs as small grains $\left(\mathrm{Bt}_{1 \mathrm{i}}\right)$ included in spinel, sapphirine and orthopyroxene (Fig. 5a, b, c). Rare inclusions of mesoperthite (Kfs) are found in the orthopyroxene porphyroblasts that occur at the margins of the domain (Fig. 4a). Cordierite $\left(\mathrm{Crd}_{2}\right)$ is a post-peak mineral and occurs as grains and coronas $(\leq 1.0 \mathrm{~mm})$ (Figs. 4b, 5c) that isolate biotite, orthopyroxene and sapphirine from each other (Figs. 4a, b, 5a, b).

Domain II is the inner rim of the layer (and the boudin). It is never in direct contact with the charnockite host, but rather constitutes an intermediate area between domains I and III. The peak assemblage consists of sillimanite, orthopyroxene, sapphirine, biotite, K-feldspar and plagioclase in the layer (samples 155A, $155 \mathrm{C}$ and $155 \mathrm{C} 4$, Table 1; Fig. 4a) and in the boudin (sample 155C5, Table 1; Fig. 4b). Sillimanite occurs as either prismatic grains ( Sill $_{1}, 0.5-8.0 \mathrm{~mm}$ long) with spinel $\left(\mathrm{Spl}_{1 \mathrm{i}}\right)$ inclusions (Fig. $5 \mathrm{~d}$ ) or as inclusions ( Sill $\left._{1 \mathrm{i}}\right)$ up to $0.3 \mathrm{~mm}$ without spinel inclusions (Fig. 5e). Orthopyroxene $\left(\mathrm{Opx}_{1}\right)$ occurs as porphyroblasts (0.3-4.0 mm long) (Fig. 5e) and sapphirine is rare and occurs as inclusions $\left(\mathrm{Spr}_{1 \mathrm{i}}\right)$ in sillimanite (Fig. 5d). Biotite occurs as rare inclusions $\left(\mathrm{Bt}_{1 \mathrm{i}}\right)$ in perthite $(\mathrm{Pt})$, and as porphyroblasts $\left(\mathrm{Bt}_{1}, 0.3-\right.$ 
$0.8 \mathrm{~mm}$ long) around sillimanite and orthopyroxene (Fig. 5d, e). Some of the biotite porphyroblasts contain rare inclusions of ilmenite (Ilm) (Fig. 5e). Mesoperthite is included in, or surrounded by biotite (Fig. 5d) while plagioclase ( $\mathrm{Pl}, 0.3-0.9 \mathrm{~mm}$ long) is in contact with biotite orthopyroxene and sillimanite porphyroblasts (Fig. 5d, e). Cordierite $\left(\mathrm{Crd}_{2}\right)$ is the main post-peak mineral produced at the expense of the peak mineral assemblage and occurs as moat and symplectite microstructures (samples 155C4 and 155C5, Table 1). The moats are composed of grains up to $0.7 \mathrm{~mm}$ long (Fig. $5 \mathrm{~d}$, e), that contain small inclusions $(\leq 0.2 \mathrm{~mm})$ of sapphirine and sillimanite (Fig. 5e). The symplectites show minor lamellae and/or globules of spinel $\left(\mathrm{Spl}_{2}\right)$ closely intergrown with magnetite grains (Mag) (Fig. 5f), and occur in contact with sillimanite and close to orthopyroxene porphyroblast (Fig. 5f). One of the symplectites contains minute crystals $(\leq 0.1 \mathrm{~mm})$ of corundum ( $\mathrm{Crn}$ ) and is located between biotite and sillimanite (Fig. $5 \mathrm{f}$ ). Symplectites of $\mathrm{Crd}_{2}+\mathrm{Spl}_{2}+\mathrm{Mag}$ are also observed at the transition

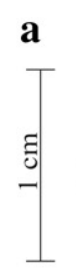

Domain III

II

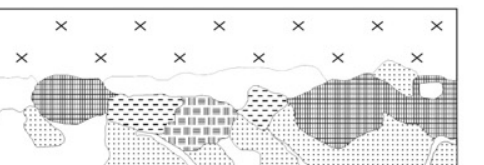

(1)

Domain I

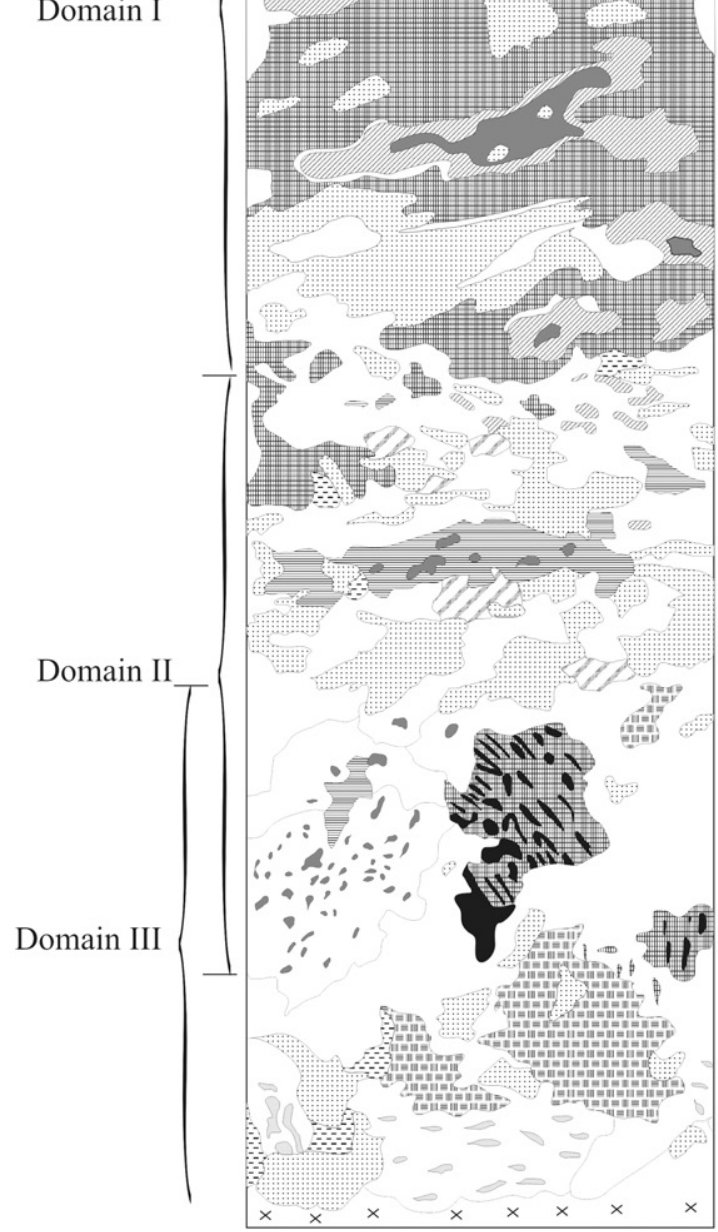

\section{INDEX}

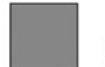

Spinel $_{1}$

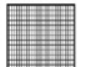

Orthopyroxene $_{1}$

Biotite

Sapphirine

Sillimanite

Garnet

Cordierite

Perthite or

Mesoperthite

Plagioclase

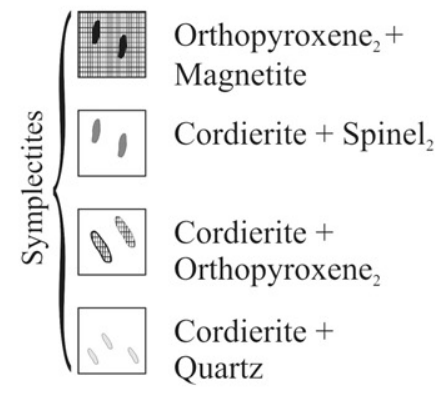

$\begin{array}{lll}x \times & \text { Charnockite } \\ x \times & \end{array}$

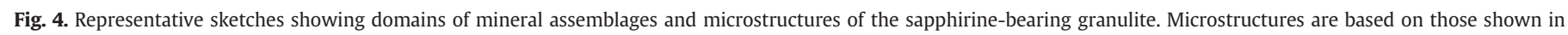
Figs. 5 and 6. (a) sketch of section across the sapphirine-bearing layer shown in Fig. 3a; (b) sketch of section across the sapphirine-bearing boudin shown in Fig. 3b. 
b

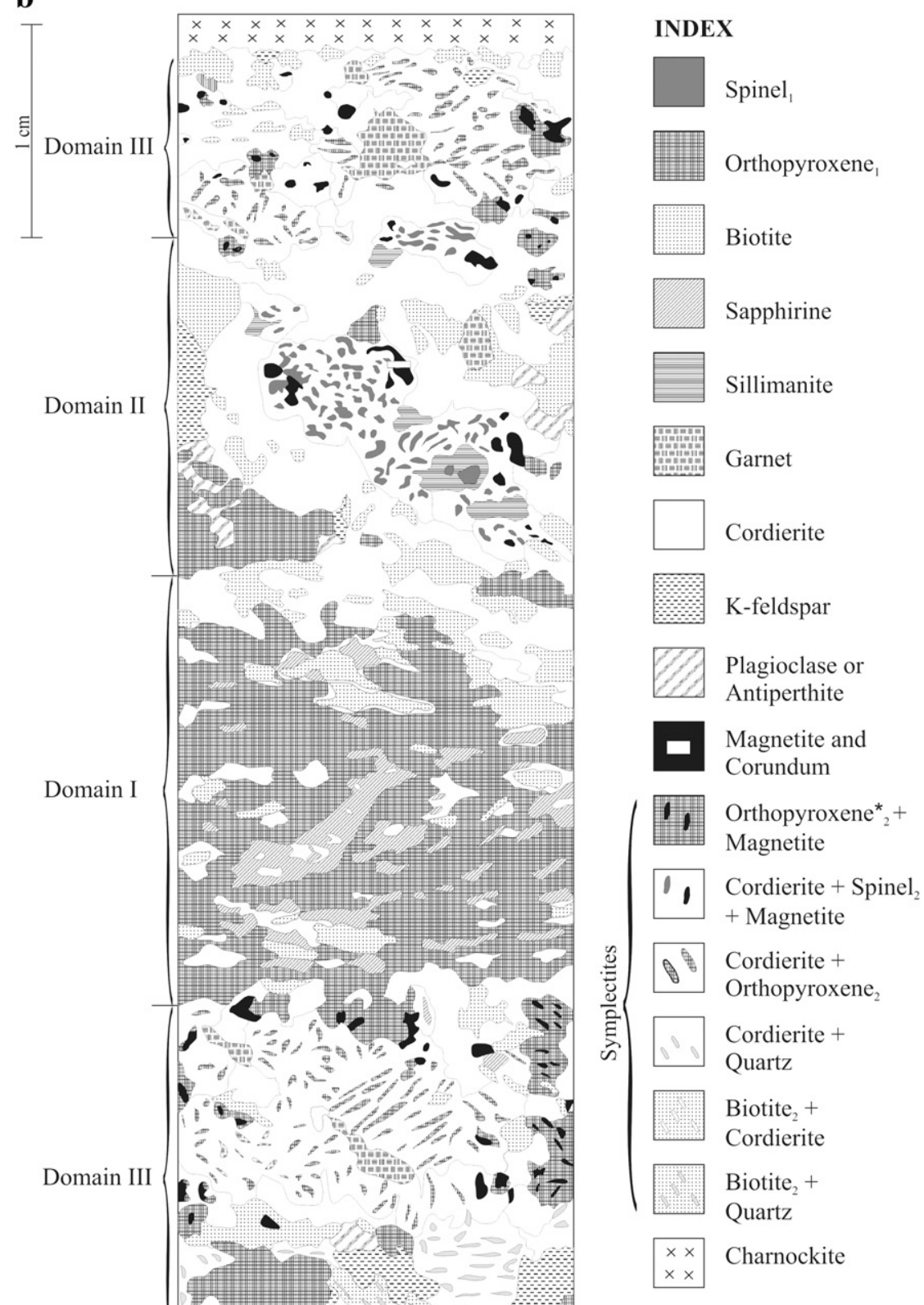

Fig. 4 (continued).

between Domains II and III, close to the symplectites of orthopyroxene $\left(\mathrm{Opx}_{2}^{*}\right)$ with exsolution lamellae of magnetite (Figs. 5g, 6a).

Domain III occurs at the contact between the sapphirine-bearing granulite and the charnockite (Fig. 4a, b). The peak mineral assemblage contains garnet, orthopyroxene ${ }_{1}$, biotite ${ }_{1}$, K-feldspar and plagioclase in the layer (samples 155C4 and 155F, Table 1; Fig. 4a) and the boudin (samples 155C5 and 155C2, Table 1; Fig. 4b). In the outer part of this domain garnet occurs as aggregates surrounded by biotite-rich selvages (Fig. 3a). In contrast, within the domain, garnet $\left(\mathrm{Grt}_{1}\right)$ occurs as xenomorphic grains (Fig. 6a) and porphyroblasts (0.3-5.0 mm long), with biotite inclusions (Fig. 6b). Orthopyroxene appears as xenomorphic porphyroblasts (up to $2.0 \mathrm{~mm}$ long) with inclusions of mesoperthite (Fig. 6c). Biotite occurs as inclusions in mesoperthite (Fig. 6a) or as porhyroblasts (up to $0.6 \mathrm{~mm}$ long, Fig. 6b). Plagioclase, mesoperthite, perthite and antiperthite (APt) occur in the outer rim of the domain
(Figs. 5f, g, 6a, c). The post-peak assemblage consists of cordierite moats around garnet $_{1}$ and orthopyroxene ${ }_{1}$ (Figs. 5g, 6a, b) and cordieritebearing symplectites that may contain orthopyroxene ${ }_{2}$, cordierite ${ }_{2}$ and biotite $_{2}$ or quartz in the layer (samples $155 \mathrm{C} 4$ and 155F, Fig. 4a) and in the boudin (samples 155C5 and 155C2, Fig. 4b). Orthopyroxene occurs either as porhyroblasts $\left(\mathrm{Opx}_{2}^{*}\right)$ with magnetite lamellae/globules (Figs. $5 \mathrm{~g}, 6 \mathrm{a}, \mathrm{b}$ ) or as symplectites $\left(\mathrm{Opx}_{2}\right)$ in host cordierite surrounding garnet (Fig. 6a, b). Symplectites consisting of cordierite with minor lamellae of biotite $\left(\mathrm{Bt}_{2}\right)$ or quartz (Qtz) are developed at the expense of garnet and orthopyroxene only in the outer rim of the Domain III when they are in contact with the charnockite (Fig. 6b, c). In the same reaction sites mesoperthite is bordered by antiperthite and myrmekite $(\mathrm{Myr})$ and biotite ${ }_{2}$-quartz symplectite occurs between mesoperthite and orthopyroxene ${ }_{1}$ (Fig. 6c). Zircon (Zrc) and monazite (Mnz) appear as small inclusions in cordierite, biotite $_{1}$ and orthopyroxene ${ }_{1}$ (Fig. 6b, c). 
Table 1

Chemical data and mineral assemblages present in sapphirine-bearing granulite and host charnockite

\begin{tabular}{|c|c|c|c|c|c|c|c|c|c|}
\hline \multirow{4}{*}{$\begin{array}{l}\text { Sample/ } \\
\text { rock }\end{array}$} & 155 & $155 B$ & $155 A$ & $155 C$ & $155 C 4$ & $155 \mathrm{C} 5$ & $155 \mathrm{C} 2$ & $155 \mathrm{~F}$ & $155 \mathrm{E}$ \\
\hline & SprGr & SprGr & SprGr & SprGr & SprGr & SprGr & SprGr & SprGr & Charno \\
\hline & & & & & $\mathrm{La}$ & & & & \\
\hline & D I & D I & D II & D II & D II and III & D II and III & D III & D III & \\
\hline \multicolumn{10}{|l|}{ Minerals } \\
\hline $\mathrm{Opx}_{1}$ & $0.67-0.69$ & $0.69-0.70$ & $0.66-0.74$ & $\mathrm{X}$ & $0.65-0.66$ & $0.66-0.68$ & $0.66-0.67$ & $\mathrm{X}$ & $0.70-0.72$ \\
\hline $\mathrm{Opx}_{2}$ & & & & & $0.63-0.64$ & $0.66-0.69$ & $0.62-0.64$ & $\mathrm{X}$ & \\
\hline $\mathrm{Spl}_{1 \mathrm{i}}$ & $0.39-0.69$ & & $0.44-0.53$ & $\mathrm{X}$ & & $0.44-0.46$ & & & \\
\hline $\mathrm{Spl}_{2}$ & & & $0.36-0.38$ & $X$ & $0.36-0.39$ & $0.36-0.39$ & & & \\
\hline Grt & & & & & $0.47-0.49$ & $0.39-0.48$ & $0.41-0.47$ & $X$ & $X$ \\
\hline Sill & & & $\mathrm{X}$ & $X$ & $\mathrm{X}$ & $\mathrm{X}$ & & & \\
\hline Spr & $0.73-0.79$ & $0.75-0.78$ & $0.75-0.81$ & $\mathrm{X}$ & & & & & \\
\hline Crd & $0.82-0.86$ & $0.85-0.86$ & $0.78-0.87$ & $\mathrm{X}$ & $0.82-0.85$ & $0.83-0.84$ & $0.83-0.84$ & $\mathrm{X}$ & \\
\hline $\mathrm{Bt}_{1 \mathrm{i}}$ & $1.68-3.09$ & $1.77-2.43$ & $2.21-3.15$ & $\mathrm{X}$ & $3.10-5.25$ & $\mathrm{X}$ & $\mathrm{X}$ & $X$ & $4.55-5.34$ \\
\hline $\mathrm{Bt}_{1}$ & $5.24-5.50$ & $5.28-5.53$ & $\mathrm{X}$ & $\mathrm{X}$ & $5.24-5.53$ & $\mathrm{X}$ & $5.28-5.55$ & $X$ & $4.60-5.21$ \\
\hline $\mathrm{Bt}_{2}$ & & & & & $4.28-6.05$ & $\mathrm{X}$ & $3.41-5.64$ & $\mathrm{X}$ & $\mathrm{X}$ \\
\hline Kfs & & & & & $\mathrm{X}$ & $\mathrm{X}$ & $\mathrm{X}$ & $\mathrm{X}$ & $\mathrm{X}$ \\
\hline $\mathrm{Pt}$ & & & & & & $\mathrm{X}$ & $X$ & $\mathrm{X}$ & $X$ \\
\hline Pl & & & & & $\mathrm{X}$ & $\mathrm{X}$ & $\mathrm{X}$ & $\mathrm{X}$ & $X$ \\
\hline $\mathrm{APt}$ & & & & & $\mathrm{X}$ & & $\mathrm{X}$ & $\mathrm{X}$ & $\mathrm{X}$ \\
\hline Qtz & & & & & & & $\mathrm{X}$ & $\mathrm{X}$ & $\mathrm{X}$ \\
\hline Mag & & & $X$ & $X$ & $\mathrm{X}$ & $\mathrm{X}$ & $\mathrm{X}$ & $\mathrm{X}$ & $\mathrm{X}$ \\
\hline $\mathrm{Ilm}$ & & & & $X$ & & & & & $X$ \\
\hline Crn & & & & & & $X$ & & & \\
\hline
\end{tabular}

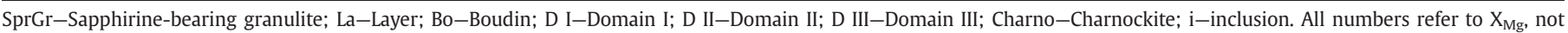

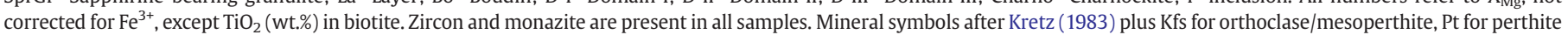
and APt for antiperthite.

\subsection{Charnockite}

The charnockite contains up to $12 \%$ in volume of orthopyroxene with biotite in addition to feldspar, and quartz (sample 155E). Garnet, which is restricted to the contact with the sapphirine-bearing granulite, occurs as porphyroblasts, up to $9.0 \mathrm{~mm}$ in diameter, that contain biotite and plagioclase inclusions (Fig. 6d). Orthopyroxene porphyroblasts are $2.0-8.0 \mathrm{~mm}$ long and they have biotite inclusions $\left(\mathrm{Bt}_{1}\right)$. A special kind of microstructure involving the orthopyroxenegarnet pair is observed where they are in contact with perthite and plagioclase. Garnet rims contain small orthopyroxene crystals (Fig. 6d) in a situation which resembles "dragging"-microstructures (Jessel, 1987). Biotite also appears as porphyroblasts $\left(\mathrm{Bt}_{1}\right)$, which are 2.0 $8.0 \mathrm{~mm}$ long. Perthite and antiperthite occur as porphyroblasts up to $1.0 \mathrm{~cm}$ long, the latter mostly substituting mesoperthite. Quartz appears as interstitial grains or composes aggregates mantling orthopyroxene or garnet. The only symplectites present are composed of biotite $\left(\mathrm{Bt}_{2}\right)$ and quartz that occur at the margins of biotite $\left(\mathrm{Bt}_{1}\right)$ porphyroblasts in contact with mesoperthite. Zircon and monazite also occur as small inclusions in orthopyroxene, mesoperthite, antiperthite and biotite.

\section{Mineral chemistry}

\subsection{Analytical procedure}

Mineral compositions were obtained using a Cameca SX 100 electron microprobe analyser in the Electron Microprobe Laboratory at Université Blaise Pascal in Clermont Ferrand, France. Operating conditions were $15 \mathrm{kV}, 15 \mathrm{nA}, 5-10 \mu \mathrm{m}$ beam size and counting time of $10 \mathrm{~s}$. Natural silicates were used as standards for most elements, except for $\mathrm{Zn}$ which was calibrated using synthetic sphalerite, and $\mathrm{F}$ using natural fluorite. Ferric iron contents in mineral structural formulae were estimated using NORM software, version 4.0 (Ulmer, 1993) where ${ }^{\mathrm{VI}} \mathrm{Fe}^{3+}={ }^{\mathrm{IV}} \mathrm{Al}^{3+}-\left({ }^{\mathrm{VI}} \mathrm{Al}^{3+}+\mathrm{Cr}_{\mathrm{TOTAL}}\right)$. The exceptions are for garnet $\left(\mathrm{Fe}^{3+}=4-\left(\mathrm{Al}^{\mathrm{VI}}+\mathrm{Ti}+\mathrm{Cr}\right)\right)$, spinel (Bohlen and Essene, 1977) and sapphirine (Higgins et al., 1979).

\subsection{Orthopyroxene}

Orthopyroxene shows slight chemical zoning of $\mathrm{X}_{\mathrm{Mg}}$ and $\mathrm{Al}_{2} \mathrm{O}_{3}$ (Table 2). $O p x_{1}$ porphyroblasts have $X_{\mathrm{Mg}}$ varying from 0.67 to 0.70 in sapphirine-bearing granulite and from 0.70 to 0.72 in the charnockite. Orthopyroxene grains either with magnetite exsolution lamellae $\left(\mathrm{Opx}_{2}^{*}\right)$ or as lamellae $\left(\mathrm{Opx}_{2}\right)$ in cordierite have $\mathrm{X}_{\mathrm{Mg}}$ of 0.65 and 0.63 , respectively. The $\mathrm{Al}_{2} \mathrm{O}_{3}$ content of $\mathrm{Opx}_{1}$ varies from 8.33 to 10.38 wt.\% in sapphirine-bearing granulite and from 8.94 to 9.55 wt.\% in charnockite while in $\mathrm{Opx}_{2}^{*}$ and $\mathrm{Opx}_{2}$ ranges from 7.50 to 6.18 wt.\%. The $y$ (opx) values (i.e. cations of $\mathrm{Si}+\mathrm{Al}-2$, with $\mathrm{Fe}^{3+}$ recalculation) show variations of $0.139-0.203,0.166-0.179$ and $0.123-0.130$ in $0_{p x}$ of the Domains I, II and III, respectively. For Opx* the $y(\mathrm{opx})$ values vary from 0.103 to 0.119 , and for $\mathrm{Opx}_{2}$ from 0.119 to 0.122 . Al and $X_{\mathrm{Mg}}$ zonation varies according to the mineral assemblages and rock type. The $\mathrm{Opx}_{1}$ mantled by feldspar or biotite ${ }_{2}$ in both rock types have $X_{\mathrm{Mg}}$ increasing rimward. In contrast, $\mathrm{Opx}_{1}$ surrounded by cordierite show lower $X_{\mathrm{Mg}}$ at the rims. $\mathrm{Opx}_{1}$ shows $\mathrm{Al}_{2} \mathrm{O}_{3}$ decreasing rimward (10.38 to $6.19 \mathrm{wt} . \%)$ in sapphirine-bearing granulite and the opposite pattern (8.94 to 9.55 wt.\%) in charnockite.

\subsection{Spinel}

Spinel is essentially a spinel-hercynite solid solution (Table 3) with $X_{\mathrm{Mg}}$ varying from 0.38 (hercynite-rich solution) to 0.72 (spinelrich solution). Hercynite component increases rimward in spinel $\left(\mathrm{Spl}_{1}\right)$ inclusions. In contrast, the spinel component increases rimward in symplectite $\left(\mathrm{Spl}_{2}\right)$. Recalculation of spinel composition according to stoichiometry (Bohlen and Essene, 1977) gives 1.534.30 wt.\% $\mathrm{Fe}_{2} \mathrm{O}_{3}$ in $\mathrm{Spl}_{1}$ and $1.76-3.89$ wt.\% $\mathrm{Fe}_{2} \mathrm{O}_{3}$ in $\mathrm{Spl}_{2}$. $\mathrm{ZnO}$ contents are higher in $\mathrm{Spl}_{1}$ (1.86 to $3.35 \mathrm{wt} . \%$ ) and ranging from 1.15 to $1.76 \mathrm{wt} . \%$ in $\mathrm{Spl}_{2}$. 

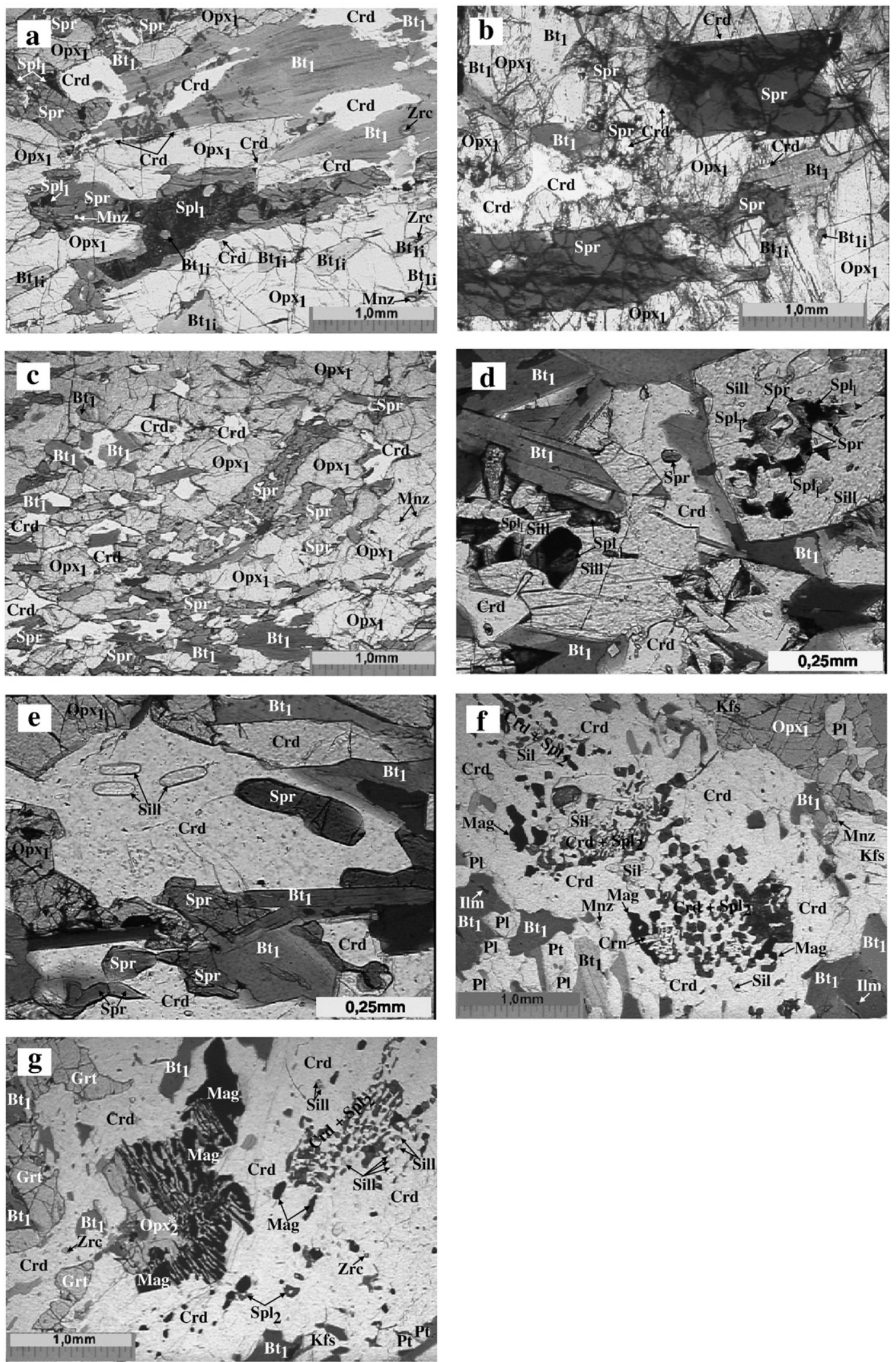

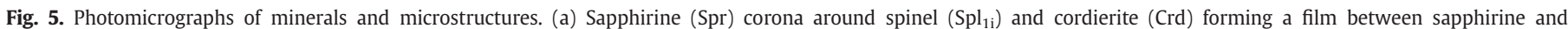

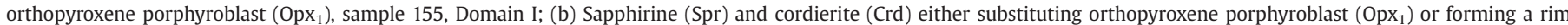

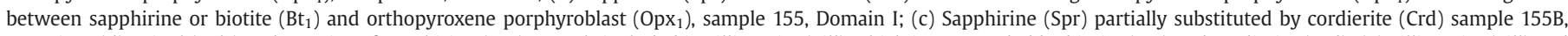

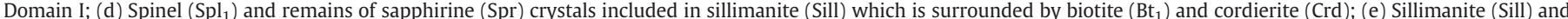

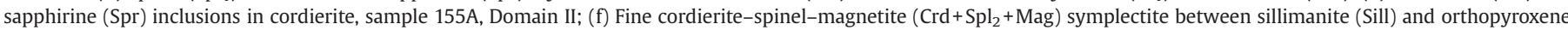

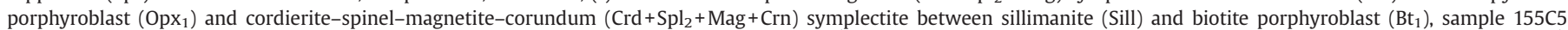

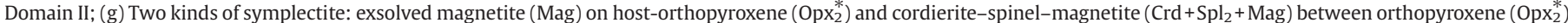
and sillimanite (Sill), sample 155C5, Domains II and III. 

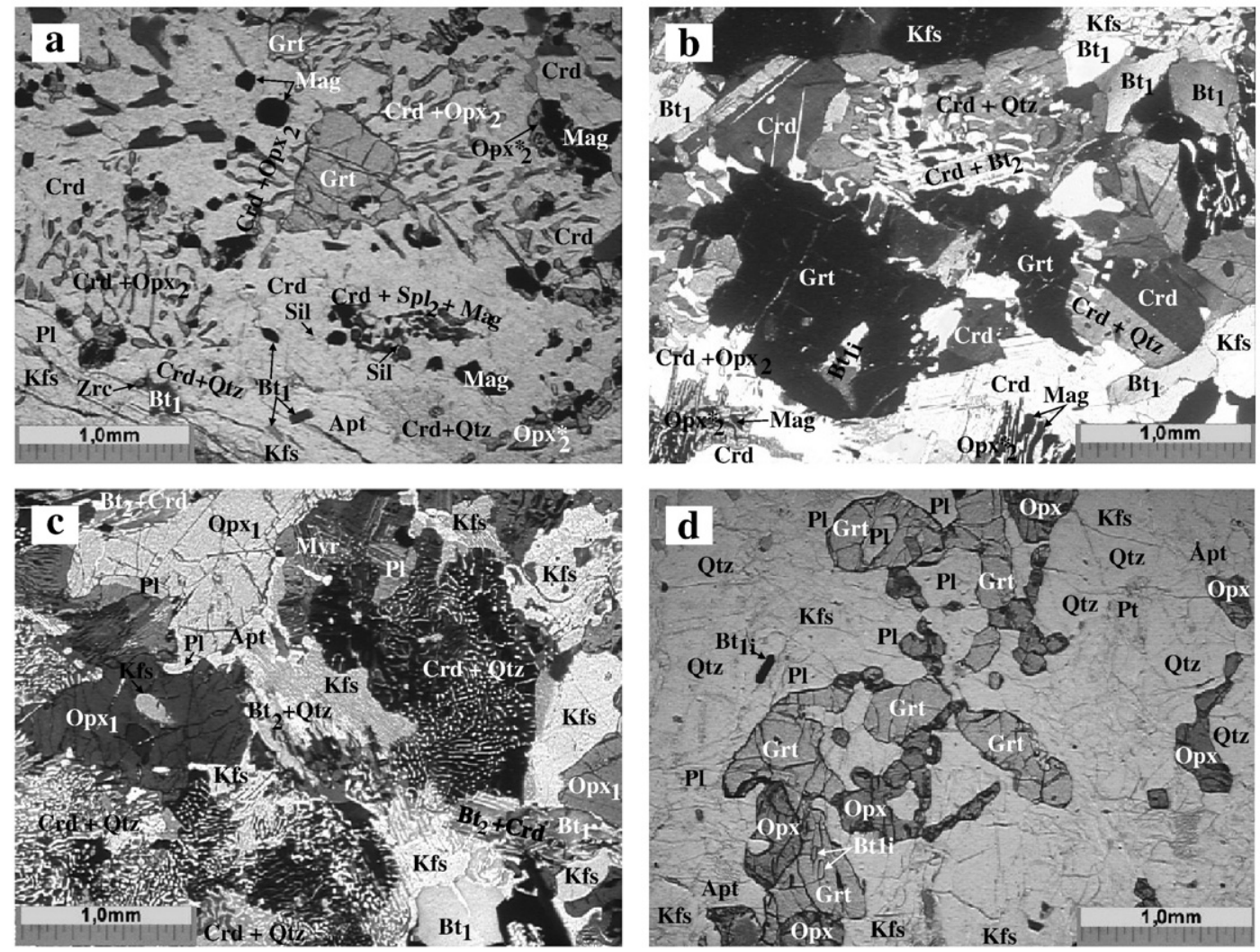

Fig. 6. Photomicrographs of minerals and microstructures. (a) Fine cordierite-orthopyroxene ${ }_{2}\left(\mathrm{Crd}+\mathrm{Opx}_{2}\right)$ symplectite between garnet ( $\mathrm{Grt}$ ) and orthopyroxene ( $\left.\mathrm{Opx}{ }_{2}^{*}\right)$ with exsolved magnetite (Mag), sample 155C5, Domain III; (b) Cordierite symplectites formed through garnet consuming reactions: at the garnet (Grt) border against orthopyroxene (Opx:), the symplectite has orthopyroxene $\left(\mathrm{Opx}_{2}\right)$ lamellae whereas at the rim against mesoperthite (Kfs) the symplectite has quartz lamellae and cordierite shows intergrowth with biotite $\left(\mathrm{Bt}_{2}\right)$, sample 155C4, Domain III; (c) Symplectites controlled by the presence of melt (now represented by mesoperthite (Kfs) crystals) that reacted with orthopyroxene (Opx ${ }_{1}$ ): cordierite $(\mathrm{Crd})+$ quartz $(\mathrm{Qtz})$, biotite $\left(\mathrm{Bt}_{2}\right)+$ quartz $(\mathrm{Qtz})$ and cordierite $(\mathrm{Crd})+$ biotite $\left(\mathrm{Bt}_{2}\right)$, note also the presence of antiperthite ( $\mathrm{APt}$ ) and myrmekite (Myr), sample $155 \mathrm{C} 2$, Domain III; (d) Garnet (Grt) forming “dragging”-microstructures (Jessel, 1987) over orthopyroxene (Opx), sample 155F, charnockite.

\subsection{Sapphirine}

Sapphirine shows compositional zoning depending on the coexisting phases. Grains with spinel inclusions and in contact with $\mathrm{Opx}_{1}$ have slight $X_{\mathrm{Mg}}$ increasing rimward, while sapphirine inclusions in Crd show a decreasing pattern (Table 4). Sapphirine included in cordierite is the most aluminous ( $\mathrm{Al}^{\text {Tot. }}$ : 8.43-8.57 a.p.f.u.), while those containing spinel inclusions and in contact with $\mathrm{Opx}_{1}$ or Crd have lower aluminium ( $\mathrm{Al}^{\mathrm{Tot}}$ : 8.32-8.45 a.p.f.u.). Sapphirine compositions, recalculated following Higgins et al. (1979), have $\mathrm{Fe}_{2} \mathrm{O}_{3}$ varying from 3.53 to $5.15 \mathrm{wt} . \%$. Sapphirine compositions occur off the tie line joining the 2:2:1 and 7:9:3 end members (Fig. 7).

\subsection{Garnet}

Garnet is an almandine-pyrope solid solution with minor spessartine and grossular contents (Table 5). The pyrope component decreases from the core (39-42 $\mathrm{mol} \%$ ) to the rim (35-40 mol\%) while almandine, spessartine and grossular increase rimward from 50 to $54 \mathrm{~mol} \%, 4.0$ to $6.0 \mathrm{~mol} \%$ and 2.3 to $4.2 \mathrm{~mol} \%$, respectively. Profiles of $\mathrm{Ca}, \mathrm{Mg}$, Fe and Mn concentrations show a mirror image between $\mathrm{Mg}$ and Fe and enrichment at rims of Ca, Fe and Mn (Fig. 8).

\subsection{Cordierite}

Cordierite has only minor compositional variation whether it forms rims around sapphirine and orthopyroxene or occurs as moats and symplectites (Table 6). Grains adjacent to sapphirine are the most magnesian $\left(X_{\mathrm{Mg}}\right.$ : 0.86-0.87) whereas grains forming symplectites with quartz are more iron-rich $\left(X_{\mathrm{Mg}}: 0.83\right)$. The high wt.\% totals suggest low contents of fluid species $\left(\mathrm{H}_{2} \mathrm{O}, \mathrm{CO}_{2}\right)$ in the structural channels.

\subsection{Biotite}

Biotite is phlogopite rich (Fig. 9a). Biotite porphyroblasts $\left(\mathrm{Bt}_{1}\right)$ in sapphirine-bearing granulite are richer in $X_{\mathrm{Mg}}(0.78-0.81)$ and $\mathrm{F}(1.62-$ 2.06 wt.\%) than the small inclusions $\left(\mathrm{Bt}_{1 \mathrm{i}}\right.$ with $X_{\mathrm{Mg}}$ : $0.69-0.75$ and $\mathrm{F}$ : $1.15-1.51$ wt.\%) and biotite in symplectites $\left(\mathrm{Bt}_{2}\right.$ with $X_{\mathrm{Mg}}: 0.67-0.68$ and F: $0.54-1.39$ wt.\%) with quartz or cordierite (Table 7). Biotite in charnockite has $X_{\mathrm{Mg}}$ between 0.69 and 0.73 , F from 0.30 to 0.48 wt.\% and $X_{\mathrm{Fe}}$ between 0.27 and $0.30 . \mathrm{Bt}_{2}$ tends to be richer in $\mathrm{TiO}_{2}(0.463-$ 0.605 Ti a.p.f.u.) than $\mathrm{Bt}_{1 \mathrm{i}}\left(0.337-0.580\right.$ Ti a.p.f.u.) and $\mathrm{Bt}_{1}(0.223-0.257 \mathrm{Ti}$ a.p.f.u.). There is also a negative correlation between $X_{\mathrm{Mg}}$ and Ti (Fig. 9b) which can be explained by the substitution $\left(\mathrm{Ti}^{4+}\right)^{\mathrm{VI}}+()^{\mathrm{VI}} \Leftrightarrow 2\left(\mathrm{Mg}^{2+}\right)^{\mathrm{VI}}$ (Guidotti, 1984) or $\left(\mathrm{Ti}^{4+}\right)^{\mathrm{IV}}+()^{\mathrm{VI}} \Leftrightarrow\left(\mathrm{Mg}^{2+}\right)^{\mathrm{IV}}+\left(\mathrm{Mg}^{2+}\right)^{\mathrm{VI}}$ (White et al., 2002). Although differences in $X_{\mathrm{Mg}}$ between core and rim are subtle, $\mathrm{F}$ decreases towards the rims, while Ti increases (Table 7) which can be explained by the substitution $\left(\mathrm{Ti}^{4+}\right)^{\mathrm{IV}}+\left(\mathrm{O}^{2-}\right)^{\mathrm{HD}} \Leftrightarrow\left(\mathrm{Mg}^{2+}\right)^{\mathrm{IV}}+2\left(\mathrm{OH}, \mathrm{F}^{1-}\right)^{\mathrm{HD}}$ (Henry and Guidotti, 2002) where HD represents the hydroxyl site.

\subsection{Plagioclase}

Plagioclase is an oligoclase $\left(\mathrm{An}_{24-27}\right)$. In general, $\mathrm{Na}$ increases slightly rimwards in the individual grains (Table 8). In charnockite, the anorthite content is higher $\left(\mathrm{An}_{27}\right)$ in antiperthite intergrowths than matrix plagioclase rims $\left(\mathrm{An}_{25}\right)$ (Table 8$)$. 
Table 2

Representative orthopyroxene analyses

\begin{tabular}{|c|c|c|c|c|c|c|c|c|c|c|c|c|}
\hline \multirow{4}{*}{$\begin{array}{l}\text { Sample/ } \\
\text { rock }\end{array}$} & 155 & 155 & $155 B$ & $155 B$ & $155 \mathrm{~A}$ & $155 \mathrm{~A}$ & $155 C 4$ & $155 C 4$ & $155 C 5$ & $155 C 5$ & $155 \mathrm{E}$ & $155 \mathrm{E}$ \\
\hline & SprGr & SprGr & SprGr & SprGr & SprGr & SprGr & SprGr & SprGr & SprGr & SprGr & Charno & Charno \\
\hline & $\mathrm{La}$ & La & Bo & Bo & La & $\mathrm{La}$ & $\mathrm{La}$ & $\mathrm{La}$ & Bo & Bo & & \\
\hline & D I & D I & D I & D I & D II & D II & D II & D II & D III & D III & & \\
\hline Position & $\mathrm{A} 11 \mathrm{cP}$ & $\mathrm{A} 12 \mathrm{rP}$ & $\mathrm{A} 16 \mathrm{cP}$ & A15rP & $\mathrm{A} 01 \mathrm{cP}$ & $\mathrm{A} 02 \mathrm{rP}$ & $\mathrm{A} 34 \mathrm{cE}$ & A33rE & A41L & $\mathrm{A} 50 \mathrm{cP}$ & $\mathrm{A} 39 \mathrm{cP}$ & A40rP \\
\hline $\mathrm{SiO}_{2}$ & 48.99 & 47.74 & 46.66 & 47.33 & 46.59 & 47.03 & 47.90 & 48.76 & 48.50 & 47.52 & 46.99 & 46.63 \\
\hline $\mathrm{TiO}_{2}$ & 0.01 & 0.05 & 0.03 & 0.02 & 0.12 & 0.08 & 0.14 & 0.12 & 0.05 & 0.08 & 0.10 & 0.22 \\
\hline $\mathrm{Al}_{2} \mathrm{O}_{3}$ & 10.10 & 9.07 & 9.64 & 8.71 & 10.38 & 9.65 & 7.50 & 6.19 & 6.18 & 8.78 & 8.94 & 9.55 \\
\hline $\mathrm{Cr}_{2} \mathrm{O}_{3}$ & 0.00 & 0.00 & 0.00 & 0.00 & 0.00 & 0.01 & 0.01 & 0.03 & 0.04 & 0.01 & 0.00 & 0.00 \\
\hline $\mathrm{Fe}_{2} \mathrm{O}_{3}$ & 0.97 & 4.11 & 4.08 & 2.77 & 3.23 & 3.12 & 3.30 & 2.22 & 1.29 & 4.18 & 4.87 & 5.21 \\
\hline $\mathrm{FeO}$ & 18.73 & 17.50 & 16.35 & 16.98 & 17.56 & 17.98 & 19.25 & 19.79 & 20.79 & 18.34 & 16.82 & 15.44 \\
\hline $\mathrm{MnO}$ & 0.26 & 0.35 & 0.30 & 0.24 & 0.30 & 0.34 & 0.56 & 0.61 & 0.45 & 0.33 & 0.23 & 0.16 \\
\hline $\mathrm{MgO}$ & 22.11 & 21.95 & 21.91 & 22.04 & 21.19 & 21.24 & 20.74 & 21.22 & 20.42 & 21.41 & 21.98 & 22.55 \\
\hline $\mathrm{CaO}$ & 0.07 & 0.02 & 0.08 & 0.03 & 0.06 & 0.02 & 0.05 & 0.06 & 0.11 & 0.05 & 0.01 & 0.03 \\
\hline $\mathrm{Na}_{2} \mathrm{O}$ & 0.01 & 0.03 & 0.00 & 0.00 & 0.01 & 0.02 & 0.10 & 0.00 & 0.04 & 0.00 & 0.01 & 0.03 \\
\hline $\mathrm{K}_{2} \mathrm{O}$ & 0.01 & 0.00 & 0.00 & 0.02 & 0.02 & 0.01 & 0.03 & 0.04 & 0.02 & 0.00 & 0.00 & 0.00 \\
\hline Total & 101.3 & 100.8 & 99.04 & 98.14 & 99.45 & 99.49 & 99.57 & 99.04 & 97.90 & 100.7 & 99.93 & 99.81 \\
\hline 0 & 6.000 & 6.000 & 6.000 & 6.000 & 6.000 & 6.000 & 6.000 & 6.000 & 6.000 & 6.000 & 6.000 & 6.000 \\
\hline $\mathrm{Si}$ & 1.772 & 1.748 & 1.732 & 1.769 & 1.726 & 1.744 & 1.789 & 1.829 & 1.843 & 1.749 & 1.735 & 1.715 \\
\hline $\mathrm{Ti}$ & 0.000 & 0.001 & 0.001 & 0.000 & 0.003 & 0.002 & 0.004 & 0.004 & 0.001 & 0.002 & 0.002 & 0.006 \\
\hline $\mathrm{Al}$ & 0.431 & 0.391 & 0.422 & 0.384 & 0.453 & 0.422 & 0.330 & 0.274 & 0.277 & 0.381 & 0.389 & 0.414 \\
\hline $\mathrm{Cr}$ & 0.000 & 0.000 & 0.000 & 0.000 & 0.000 & 0.000 & 0.000 & 0.001 & 0.001 & 0.000 & 0.000 & 0.000 \\
\hline $\mathrm{Fe}^{3+}$ & 0.026 & 0.113 & 0.114 & 0.078 & 0.090 & 0.087 & 0.093 & 0.063 & 0.037 & 0.116 & 0.135 & 0.144 \\
\hline $\mathrm{Fe}^{2+}$ & 0.567 & 0.536 & 0.507 & 0.531 & 0.544 & 0.558 & 0.601 & 0.621 & 0.661 & 0.564 & 0.519 & 0.475 \\
\hline $\mathrm{Mn}$ & 0.008 & 0.011 & 0.010 & 0.008 & 0.009 & 0.011 & 0.018 & 0.019 & 0.015 & 0.010 & 0.007 & 0.004 \\
\hline $\mathrm{Mg}$ & 1.192 & 1.198 & 1.212 & 1.228 & 1.170 & 1.174 & 1.155 & 1.186 & 1.157 & 1.175 & 1.210 & 1.236 \\
\hline $\mathrm{Ca}$ & 0.003 & 0.001 & 0.003 & 0.001 & 0.002 & 0.001 & 0.002 & 0.002 & 0.004 & 0.002 & 0.000 & 0.001 \\
\hline $\mathrm{Na}$ & 0.001 & 0.002 & 0.000 & 0.000 & 0.001 & 0.002 & 0.007 & 0.000 & 0.003 & 0.000 & 0.000 & 0.001 \\
\hline K & 0.001 & 0.000 & 0.000 & 0.001 & 0.001 & 0.000 & 0.001 & 0.002 & 0.001 & 0.000 & 0.000 & 0.000 \\
\hline Sum & 4.000 & 4.000 & 4.000 & 4.000 & 4.000 & 4.000 & 4.000 & 4.000 & 4.000 & 4.000 & 4.000 & 4.000 \\
\hline $\mathrm{X}_{\mathrm{Mg}}\left(\mathrm{Fe}_{2}\right)$ & 0.678 & 0.691 & 0.705 & 0.698 & 0.683 & 0.678 & 0.658 & 0.657 & 0.636 & 0.675 & 0.700 & 0.723 \\
\hline$y($ opx $)$ & 0.203 & 0.139 & 0.154 & 0.153 & 0.179 & 0.166 & 0.119 & 0.103 & 0.120 & 0.130 & 0.124 & 0.129 \\
\hline
\end{tabular}

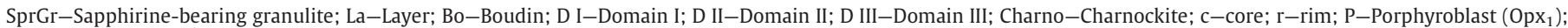
E-Symplectite $\left(\mathrm{Opx}_{2}^{*}\right)$ with exsolved magnetite; L-Symplectite lamella $\left(\mathrm{Opx}_{2}\right)$ in cordierite; $y(\mathrm{opx})=\mathrm{Si}+\mathrm{Al}-2$.

\subsection{K-feldspar}

K-feldspar composition in mesoperthite varies from $\mathrm{Or}_{78}-\mathrm{Ab}_{21}$ to $\mathrm{Or}_{88}-\mathrm{Ab}_{13}$. The re-integrated composition is estimated at $A b_{11-20}$ $\mathrm{Or}_{75-88} \mathrm{An}_{03-06}$. In antiperthite or perthite intergrowths, the $\mathrm{K}$ feldspar lamellae composition varies from $\mathrm{Or}_{92}-\mathrm{Ab}_{08}$ to $\mathrm{Or}_{94}-\mathrm{Ab}_{06}$ (Table 8).

\section{Whole rock major and trace element chemistry}

Geochemical analyses were performed on the three domains of the sapphirine-bearing granulite and the host charnockite in order to assess the role of bulk composition and mass transfer on the development of mineral assemblages in the sapphirine-bearing granulite.

The samples were analyzed at the Lakefield GEOSOL Laboratories using X-ray fluorescence and atomic absorption spectrometry for most major and trace elements. Atomic absorption spectrometry allowed the determination of low contents of $\mathrm{Na}_{2} \mathrm{O}$ (less than 1 wt.\%). $\mathrm{H}_{2} \mathrm{O}^{+}$was determined by the Penfield tube method, and $\mathrm{CO}_{2}$ was determined by liberation of the gas using $\mathrm{HCl}$ attack with heating on an oil bath at $130{ }^{\circ} \mathrm{C}$.

The analytical data (Table 9) show that from the center (Domain I, sample 155) to the rim (Domain III, sample 155C4) of the layer or boudin, the sapphirine-bearing granulite is enriched in $\mathrm{SiO}_{2}$ (from 43.3 to $62.4 \mathrm{~mol} \%$ ) whereas the contents of $\mathrm{MgO}, \mathrm{Al}_{2} \mathrm{O}_{3}$ and $\mathrm{K}_{2} \mathrm{O}$ decrease. Domain II is the richest in $\mathrm{Fe}_{2} \mathrm{O}_{3}$. These differences in bulk chemistry are reflected mineralogically, with higher amounts of spinel, sapphirine and biotite in Domain I, of magnetite in Domain II, and of quartz in Domain III. Enrichments of Rb, F and $\mathrm{Zr}$ in Domain I compared to Domains II and III are related to the abundance of biotite with inclusions of zircon.
The charnockite (sample $155 \mathrm{E}$ ) has a larger $\mathrm{SiO}_{2}$ content than rocks of the three domains of sapphirine-bearing granulite (Table 9). Its 1.64 Alumina Saturation Index suggests peraluminous magma genesis formed by partial crustal melting (see Frost et al., 2001; Frost and Frost, 2008).

\section{Interpretation of microstructures, mineral reactions and $P-T$ evolution}

The interpretation of microstructures and mineral reactions uses phase relationships that include calculated pseudosections in the $\operatorname{KFMASH}\left(\mathrm{K}_{2} \mathrm{O}-\mathrm{FeO}-\mathrm{MgO}-\mathrm{Al}_{2} \mathrm{O}_{3}-\mathrm{SiO}_{2}-\mathrm{H}_{2} \mathrm{O}\right)$ system using Perple_X'07 software (Conolly and Petrini, 2002) with the updated version of the internally consistent thermodynamic database of Holland and Powell (2001). Activity-compositions considered in this modeling are listed in Table 10 . To constrain the $P-T$ path of the mineral reactions we performed a forward petrologic modeling using $P-T$ pseudosections. The effects of variations in silica content related to melt infiltration on phase relationships are modeled using isobaric $T-M\left(\mathrm{SiO}_{2}\right)$ pseudosections.

Some of the mineral reactions are represented with phase relationships graphically portrayed in the FMAS ( $\mathrm{FeO}-\mathrm{MgO}-\mathrm{Al}_{2} \mathrm{O}_{3}-\mathrm{SiO}_{2}$ ) tetrahedron projected onto the plane $(\mathrm{F}+\mathrm{M})^{\prime}-\mathrm{Al}^{\prime}-\mathrm{Si}$ '. In these projections $\mathrm{Si}^{\prime}=\mathrm{Si}+\mathrm{Fe}^{2+}+\mathrm{Mg}-(\mathrm{Al} / 2) ; \mathrm{Mg}^{\prime}=\mathrm{Mg} ; \mathrm{Fe}^{\prime}=\mathrm{Fe}^{2+}$ and $\mathrm{Al}^{\prime}=\left(\mathrm{Al}+\mathrm{Fe}^{3+}+\right.$ $\left.\mathrm{Cr}^{3+}\right) / 2$ (Kriegsman and Schumacher, 1999).

\subsection{Microstructures and mineral reactions}

Field observations show a transitional contact between sapphirine-bearing granulite and charnockite (Fig. 3a, b). It appears clearly that the development of cordierite-bearing symplectites, is controlled 
Table 3

Representative spinel analyses

\begin{tabular}{|c|c|c|c|c|c|c|c|c|c|}
\hline \multirow{3}{*}{$\begin{array}{l}\text { Sample/ } \\
\text { rock }\end{array}$} & 155 & 155 & $155 A$ & $155 A$ & $155 \mathrm{C} 5$ & $155 A$ & $155 A$ & $155 \mathrm{C} 4$ & $155 C 4$ \\
\hline & SprGr La & SprGr La & SprGr La & SprGr La & SprGr Bo & SprGr La & SprGr La & SprGr La & SprGr La \\
\hline & D I & D I & D II & D II & D II & D II & D II & D II & D II \\
\hline Position & $\mathrm{A} 15 \mathrm{cI}_{\mathrm{spr}}$ & $\mathrm{A} 16 \mathrm{rI}_{\mathrm{spr}}$ & $\mathrm{A} 01 \mathrm{cl}_{\text {sill }}$ & $\mathrm{A} 02 \mathrm{rI}_{\text {sill }}$ & $\mathrm{A} 01 \mathrm{cl}_{\text {sill }}$ & A06cS & A07rS & $\mathrm{A} 16 \mathrm{cS}$ & A15rS \\
\hline$\overline{\mathrm{SiO}_{2}}$ & 0.01 & 0.02 & 0.01 & 0.03 & 0.06 & 0.00 & 0.00 & 0.86 & 0.02 \\
\hline $\mathrm{TiO}_{2}$ & 0.01 & 0.02 & 0.07 & 0.02 & 0.00 & 0.01 & 0.00 & 0.00 & 0.01 \\
\hline $\mathrm{Al}_{2} \mathrm{O}_{3}$ & 65.87 & 61.27 & 59.27 & 58.20 & 59.35 & 60.80 & 61.65 & 58.79 & 59.19 \\
\hline $\mathrm{Cr}_{2} \mathrm{O}_{3}$ & 0.08 & 0.05 & 0.09 & 0.06 & 0.08 & 0.04 & 0.00 & 0.10 & 0.00 \\
\hline $\mathrm{Fe}_{2} \mathrm{O}_{3}$ & 1.56 & 2.68 & 3.86 & 4.30 & 3.45 & 2.97 & 3.00 & 1.76 & 3.89 \\
\hline $\mathrm{FeO}$ & 12.51 & 23.43 & 24.19 & 24.37 & 23.64 & 21.91 & 19.54 & 26.39 & 25.21 \\
\hline $\mathrm{MnO}$ & 0.13 & 0.15 & 0.18 & 0.08 & 0.19 & 0.17 & 0.19 & 0.31 & 0.33 \\
\hline $\mathrm{ZnO}$ & 2.08 & 1.86 & 3.35 & 3.23 & 3.27 & 1.27 & 1.25 & 1.76 & 1.15 \\
\hline $\mathrm{MgO}$ & 18.35 & 10.75 & 9.18 & 8.83 & 9.44 & 11.77 & 13.43 & 8.98 & 9.51 \\
\hline $\mathrm{CaO}$ & 0.01 & 0.03 & 0.00 & 0.00 & 0.00 & 0.02 & 0.03 & 0.00 & 0.01 \\
\hline Total & 100.6 & 100.3 & 100.2 & 99.16 & 99.48 & 98.97 & 99.07 & 99.01 & 99.32 \\
\hline 0 & 4.000 & 4.000 & 4.000 & 4.000 & 4.000 & 4.000 & 4.000 & 4.000 & 4.000 \\
\hline $\mathrm{Si}$ & 0.000 & 0.001 & 0.000 & 0.001 & 0.001 & 0.000 & 0.000 & 0.024 & 0.001 \\
\hline $\mathrm{Ti}$ & 0.000 & 0.000 & 0.001 & 0.001 & 0.000 & 0.000 & 0.000 & 0.000 & 0.000 \\
\hline $\mathrm{Al}$ & 1.968 & 1.943 & 1.915 & 1.906 & 1.924 & 1.938 & 1.940 & 1.914 & 1.918 \\
\hline $\mathrm{Cr}$ & 0.002 & 0.001 & 0.002 & 0.001 & 0.002 & 0.001 & 0.000 & 0.002 & 0.000 \\
\hline $\mathrm{Fe}^{3+}$ & 0.030 & 0.054 & 0.080 & 0.090 & 0.071 & 0.061 & 0.060 & 0.037 & 0.081 \\
\hline $\mathrm{Fe}^{2+}$ & 0.265 & 0.527 & 0.555 & 0.566 & 0.544 & 0.496 & 0.436 & 0.610 & 0.580 \\
\hline $\mathrm{Mn}$ & 0.003 & 0.004 & 0.004 & 0.002 & 0.004 & 0.004 & 0.004 & 0.007 & 0.008 \\
\hline $\mathrm{Zn}$ & 0.039 & 0.037 & 0.068 & 0.066 & 0.066 & 0.025 & 0.025 & 0.036 & 0.023 \\
\hline $\mathrm{Mg}$ & 0.693 & 0.431 & 0.375 & 0.366 & 0.387 & 0.475 & 0.534 & 0.370 & 0.390 \\
\hline $\mathrm{Ca}$ & 0.000 & 0.001 & 0.000 & 0.000 & 0.000 & 0.001 & 0.001 & 0.000 & 0.000 \\
\hline Sum & 3.000 & 2.999 & 3.000 & 2.999 & 2.999 & 3.001 & 3.000 & 3.000 & 3.001 \\
\hline Spinel & 0.682 & 0.419 & 0.359 & 0.349 & 0.372 & 0.461 & 0.519 & 0.345 & 0.374 \\
\hline Hercynite & 0.261 & 0.512 & 0.531 & 0.539 & 0.523 & 0.481 & 0.423 & 0.576 & 0.556 \\
\hline Gahnite & 0.038 & 0.036 & 0.064 & 0.063 & 0.063 & 0.024 & 0.025 & 0.025 & 0.022 \\
\hline Mgferrite & 0.011 & 0.012 & 0.015 & 0.017 & 0.014 & 0.015 & 0.016 & 0.008 & 0.016 \\
\hline Franklinite & 0.001 & 0.001 & 0.003 & 0.003 & 0.002 & 0.001 & 0.001 & 0.001 & 0.001 \\
\hline Magnetite & 0.004 & 0.014 & 0.023 & 0.026 & 0.020 & 0.015 & 0.013 & 0.013 & 0.024 \\
\hline Galaxite & 0.003 & 0.004 & 0.003 & 0.002 & 0.003 & 0.004 & 0.004 & 0.003 & 0.008 \\
\hline Jacobsite & 0.000 & 0.000 & 0.000 & 0.000 & 0.000 & 0.000 & 0.000 & 0.000 & 0.000 \\
\hline $\mathrm{X}_{\mathrm{Mg}}\left(\mathrm{Fe}^{2}\right)$ & 0.723 & 0.450 & 0.403 & 0.392 & 0.416 & 0.489 & 0.550 & 0.378 & 0.402 \\
\hline
\end{tabular}

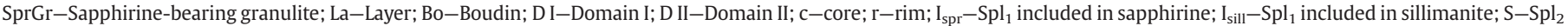
symplectite in host cordierite.

by the proximity of the charnockite (Figs. 5f, 6a, c, d). This feature suggests that part of the microstructures were probably formed by interactions between the charnockite melt and the enclaves of sapphirine-bearing granulite. If this is the case, melt would have acted both as a reactant and as an appropriate medium to enhance element diffusion to grain boundaries (Kriegsman and Hensen, 1998; Brown, 2002).

In Domains I and II, the microstructural relationships suggest that orthopyroxene $_{1}$ and spinel $_{1}$ are relict minerals. The crystallization and preservation of these two minerals indicate that melting and melt loss occurred (White and Powell, 2002). Thus spinel ${ }_{1}$ and orthopyroxene ${ }_{1}$ are considered to be peritectic products of crustal anatexis.

In Domain I, sapphirine grains may contain spinel inclusions and have cordierite rims that isolate sapphirine from orthopyroxene (Fig. 5a, b). Sapphirine may form by fluid-assisted diffusion of silica or alumina into the spinel site (Dunkley et al., 1999). Silica diffusion probably occurred as a consequence of the establishment of chemical potential gradients for $\mathrm{Si}\left(\mu_{S_{\mathrm{i}}}\right)$ between Si-rich charnockitic melt and spinel grains. Once sapphirine was formed, continued Si-diffusion would allow the growth of rims of cordierite (Fig. 5a, b) between orthopyroxene and sapphirine. FMAS projections (Fig. 10a) suggest the following continuous reactions:

$\mathrm{Spl}_{1}+\mathrm{SiO}_{2 \text { (melt) }} \Rightarrow \mathrm{Spr}$

$\mathrm{Spr}+\mathrm{Opx}_{1}+\mathrm{SiO}_{2 \text { (melt) }} \Rightarrow \mathrm{Crd}$

This Si-diffusion processes and maybe related Al-diffusion may also explain the fact that sapphirine compositions occur off the tie line joining the 2:2:1 and 7:9:3 end members (Fig. 7). It suggests extensive Ferri-Tschermak exchange: ${ }^{\mathrm{VI}}(\mathrm{Mg}, \mathrm{Fe})^{2+}+{ }^{\mathrm{IV}} \mathrm{Si}^{4+} \Leftrightarrow{ }^{\mathrm{VI}}(\mathrm{Al}, \mathrm{Fe})^{3+}+{ }^{\mathrm{IV}} \mathrm{Al}^{3+}$ during sapphirine forming and consuming reactions.

Crystallization of cordierite can also be produced by changes in $P-T$ conditions. The calculated $P-T$ pseudosection in the KFMASH system for the Domain I (Fig. 11a) shows that the peak assemblage $\left(\mathrm{Bt}_{1}+\mathrm{Opx}_{1}+\right.$ $\mathrm{Spr}+\mathrm{Kfs}+\mathrm{L}$ ) is stable in a large field at low pressure and high temperature. A decrease in temperature to $\sim 900{ }^{\circ} \mathrm{C}$ at a pressure below 8 kbar will induce the crystallization of cordierite in equilibrium with the sub-solidus peak assemblage. The sequence of mineral assemblages produced during a cooling path is summarized below:

$\mathrm{Bt}_{1}+\mathrm{Opx}_{1}+\mathrm{Spr}+\mathrm{Kfs}+\mathrm{L}($ assemblage $1, v=3)$

$\mathrm{Bt}_{1}+\mathrm{Opx}_{1}+\mathrm{Spr}+\mathrm{Kfs}+\mathrm{L}+\mathrm{Crd}$ (assemblage 2, $v=2$ )

$\mathrm{Bt}_{1}+\mathrm{Opx}_{1}+\mathrm{Kfs}+\mathrm{Spr}+\mathrm{Crd}($ assemblage 3, $v=3)$

The lack of spinel predicted by the pseudosection highlight the fact that the effective bulk composition used here is inappropriate to model pre-sapphirine-bearing assemblage. This is consistent with the hypothesis suggesting that sapphirine-bearing assemblage was produced at the expense of $\mathrm{Opx}_{1}+\mathrm{Spl}_{1}+\mathrm{Bt}_{1}$ by the addition of silica.

In Domain II, sillimanite occurs either as inclusions in cordierite (Fig. 5e) or with spinel ${ }_{1}$ and sapphirine inclusions, the latter containing remnants of spinel ${ }_{1}$ (Fig. 5d). These microstructures suggest that sillimanite was formed as a product of the destabilization of 
Table 4

Representative sapphirine analyses

\begin{tabular}{|c|c|c|c|c|c|c|c|c|}
\hline Sample rock & $\begin{array}{c}155 \\
\text { SprGr La } \\
\text { D I }\end{array}$ & $\begin{array}{c}155 \\
\text { SprGr La } \\
\text { D I }\end{array}$ & $\begin{array}{c}155 \\
\text { SprGr La } \\
\text { D I }\end{array}$ & $\begin{array}{c}155 \\
\text { SprGr La } \\
\text { D I }\end{array}$ & $\begin{array}{c}\text { 155B } \\
\text { SprGr Bo } \\
\text { D I }\end{array}$ & $\begin{array}{c}\text { 155B } \\
\text { SprGr Bo } \\
\text { D I }\end{array}$ & $\begin{array}{c}155 A \\
\text { SprGr La } \\
\text { D II }\end{array}$ & $\begin{array}{c}155 A \\
\text { SprGr La } \\
\text { D II }\end{array}$ \\
\hline Position & A18c & $\mathrm{A} 17 \mathrm{r} \square$ & A06c & $\mathrm{A07r} \square$ & A12c & $\mathrm{A} 13 \mathrm{r} \square$ & $\mathrm{A08 \textrm {C }}$ & $\mathrm{A} 07 \mathrm{rO}$ \\
\hline $\mathrm{SiO}_{2}$ & 13.54 & 12.93 & 13.49 & 12.80 & 13.15 & 13.10 & 12.89 & 12.56 \\
\hline $\mathrm{TiO}_{2}$ & 0.00 & 0.00 & 0.10 & 0.03 & 0.05 & 0.06 & 0.04 & 0.01 \\
\hline $\mathrm{Al}_{2} \mathrm{O}_{3}$ & 57.78 & 59.16 & 57.75 & 58.86 & 57.11 & 57.70 & 58.38 & 59.58 \\
\hline $\mathrm{Cr}_{2} \mathrm{O}_{3}$ & 0.03 & 0.00 & 0.00 & 0.00 & 0.01 & 0.00 & 0.00 & 0.00 \\
\hline $\mathrm{Fe}_{2} \mathrm{O}_{3}$ & 4.27 & 4.88 & 3.89 & 4.59 & 5.15 & 4.64 & 4.34 & 3.93 \\
\hline $\mathrm{FeO}$ & 8.6 & 7.27 & 8.76 & 7.65 & 7.86 & 7.90 & 7.08 & 7.39 \\
\hline $\mathrm{MnO}$ & 0.15 & 0.10 & 0.01 & 0.06 & 0.19 & 0.12 & 0.11 & 0.14 \\
\hline $\mathrm{MgO}$ & 15.16 & 15.43 & 15.06 & 15.21 & 15.16 & 15.20 & 15.55 & 15.13 \\
\hline $\mathrm{CaO}$ & 0.03 & 0.06 & 0.02 & 0.05 & 0.03 & 0.00 & 0.01 & 0.04 \\
\hline $\mathrm{Na}_{2} \mathrm{O}$ & 0.00 & 0.04 & 0.01 & 0.01 & 0.01 & 0.02 & 0.00 & 0.00 \\
\hline $\mathrm{K}_{2} \mathrm{O}$ & 0.00 & 0.03 & 0.02 & 0.00 & 0.02 & 0.00 & 0.01 & 0.02 \\
\hline Total & 99.56 & 99.90 & 99.11 & 99.27 & 98.74 & 98.74 & 98.40 & 98.81 \\
\hline 0 & 20.000 & 20.000 & 20.000 & 20.000 & 20.000 & 20.000 & 20.000 & 20.000 \\
\hline $\mathrm{Si}$ & 1.651 & 1.565 & 1.651 & 1.560 & 1.618 & 1.608 & 1.580 & 1.533 \\
\hline $\mathrm{Ti}$ & 0.000 & 0.000 & 0.009 & 0.003 & 0.005 & 0.005 & 0.003 & 0.001 \\
\hline $\mathrm{Al}$ & 8.303 & 8.439 & 8.328 & 8.457 & 8.282 & 8.349 & 8.435 & 8.573 \\
\hline $\mathrm{Cr}$ & 0.003 & 0.000 & 0.000 & 0.000 & 0.001 & 0.000 & 0.000 & 0.000 \\
\hline $\mathrm{Fe}^{3+}$ & 0.392 & 0.445 & 0.358 & 0.421 & 0.477 & 0.428 & 0.401 & 0.361 \\
\hline $\mathrm{Fe}^{2+}$ & 0.877 & 0.736 & 0.897 & 0.780 & 0.808 & 0.811 & 0.726 & 0.754 \\
\hline Mn & 0.015 & 0.011 & 0.001 & 0.006 & 0.020 & 0.012 & 0.012 & 0.015 \\
\hline $\mathrm{Mg}$ & 2.755 & 2.783 & 2.747 & 2.764 & 2.780 & 2.781 & 2.841 & 2.754 \\
\hline $\mathrm{Ca}$ & 0.003 & 0.007 & 0.002 & 0.006 & 0.003 & 0.000 & 0.001 & 0.006 \\
\hline $\mathrm{Na}$ & 0.001 & 0.009 & 0.003 & 0.003 & 0.003 & 0.004 & 0.000 & 0.000 \\
\hline K & 0.000 & 0.005 & 0.004 & 0.000 & 0.003 & 0.000 & 0.002 & 0.002 \\
\hline Sum & 14.000 & 14.000 & 14.000 & 14.000 & 14.000 & 14.000 & 14.000 & 14.000 \\
\hline$X_{\mathrm{Mg}}\left(\mathrm{Fe}^{2+}\right)$ & 0.759 & 0.791 & 0.754 & 0.780 & 0.775 & 0.774 & 0.796 & 0.785 \\
\hline
\end{tabular}

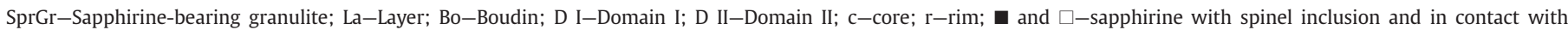
orthopyroxene $_{1}$; and $\mathrm{O}-$ sapphirine included in cordierite.

sapphirine while cordierite crystallized after sillimanite. Cordierite + spinel $_{2}$ symplectites developed at the expense of sillimanite and orthopyroxene (Fig. 5f) suggest the following continuous reaction in the FMAS system (Fig. 10b).

$\mathrm{Opx}_{1}+$ Sill $\Rightarrow \mathrm{Crd}+\mathrm{Spl}_{2}$

The enrichment in $\mathrm{Fe}_{2} \mathrm{O}_{3}$ of Domain II is expressed by the crystallization of magnetite exsolution from spinel 2 grains (Fig. 5f). Ferric iron and $\mathrm{Zn}$ are known to stabilize spinel to lower temperatures and higher pressures (e.g. Hensen, 1986; Hensen and Harley, 1990; Das et al., 2001, 2003). According to Hensen (1986) magnetite exsolves from Fe-rich spinel on cooling and the experiments of Turnock and Eugster (1962) demonstrate that a miscibility gap between spinel and magnetite exists at $T \leq 860{ }^{\circ} \mathrm{C}$. The occurrence of corundum in cordierite + spinel $_{2}+$ magnetite symplectites (Fig. 5f) also suggests that alumina would be present in excess in spinel solid solution to be exsolved on cooling. Alternatively, magnetite and corundum could be products of the following reactions controlled by increasing oxygen fugacity:

$\mathrm{Spl}_{\mathrm{sS}}+\mathrm{O}_{2} \Rightarrow \mathrm{Spl}+\mathrm{Mag}+\mathrm{Crn}$

(Viertel and Seifert, 1981)

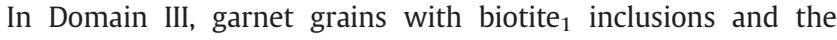
residual grains of orthopyroxene ${ }_{1}$ next to plagioclase and mesoperthite (Fig. 6b, d), suggest that orthopyroxene ${ }_{1}$ in contact with melt was partly consumed to produce garnet following the multi-variant back-melting reaction (Kriegsman and Hensen, 1998) in the (NC) KFMASH system:

$\mathrm{Opx}_{1}+\mathrm{Bt}_{1}+\mathrm{L} \Rightarrow \mathrm{Grt}+\mathrm{Kfs}(+\mathrm{Pl})$
The formation of biotite-rich selvages surrounding garnet crystals (Fig. 3a) could also be explained by garnet resorption:

$\mathrm{Grt}+\mathrm{L} \Rightarrow \mathrm{Bt}$

Garnet, orthopyroxene ${ }_{1}$ and biotite $_{1}$ facing the charnockite are mantled by symplectites comprising cordierite, biotite ${ }_{2}$ and quartz (Fig. 6b, c). The crystallization of cordierite-quartz or cordierite-

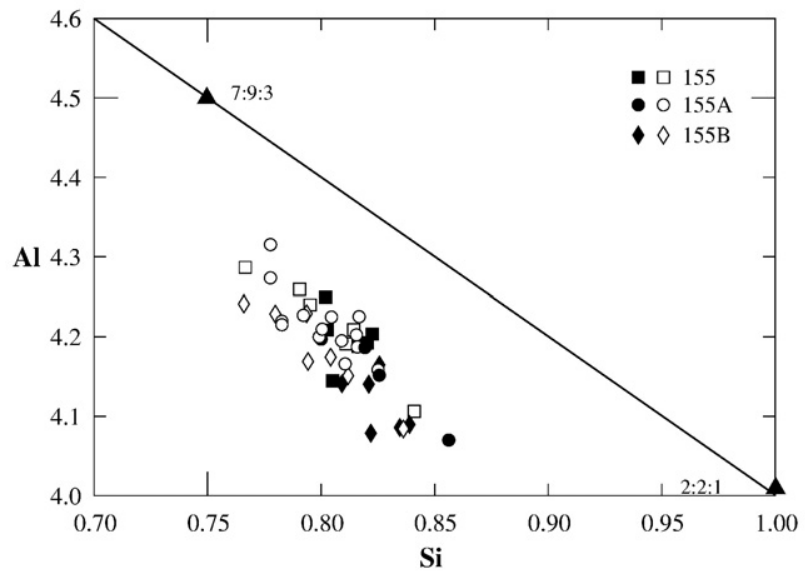

Fig. 7. The compositions of sapphirine in $\mathrm{Al}$ vs $\mathrm{Si}$ (a.p.f.u for 10 oxygens) diagram. 7:9:3 and 2:2:1 are ideal molecular ratios to $\mathrm{MgO}: \mathrm{Al}_{2} \mathrm{O}_{3}: \mathrm{SiO}_{2}$ in sapphirine (Higgins et al., 1979). The compositions fall away off the line joining 7:9:3 and 2:2:1 ideal molecular ratios suggesting Tschermak substitution ${ }^{\mathrm{VI}}(\mathrm{Mg}, \mathrm{Fe})^{+2}+\mathrm{Si}^{+4} \Leftrightarrow \mathrm{VI}(\mathrm{Al}, \mathrm{Fe})^{+3}$. In general, core compositions (filled symbols) are poorer in Al than rim compositions (open symbols) with compensation by $\mathrm{Si}$. 
Table 5

Representative garnet analyses

\begin{tabular}{|c|c|c|c|c|c|c|c|}
\hline \multirow{3}{*}{$\begin{array}{l}\text { Sample/ } \\
\text { rock }\end{array}$} & $155 C 4$ & $155 C 4$ & $155 C 4$ & $155 C 4$ & $155 C 5$ & $155 C 5$ & $155 \mathrm{E}$ \\
\hline & SprGr La & SprGr La & SprGr La & SprGr La & SprGr Bo & SprGr Bo & Charno \\
\hline & D III & D III & D III & D III & D III & D III & \\
\hline Position & A37c & A35r & A39c & A38r & A6c & A7r & $\mathrm{A} 15 \mathrm{c}$ \\
\hline$\overline{\mathrm{SiO}_{2}}$ & 39.18 & 38.68 & 38.49 & 38.39 & 38.19 & 38.56 & 38.31 \\
\hline $\mathrm{TiO}_{2}$ & 0.12 & 0.03 & 0.04 & 0.00 & 0.04 & 0.03 & 0.01 \\
\hline $\mathrm{Al}_{2} \mathrm{O}_{3}$ & 22.39 & 21.87 & 22.28 & 22.41 & 22.34 & 22.29 & 22.14 \\
\hline $\mathrm{Cr}_{2} \mathrm{O}_{3}$ & 0.00 & 0.00 & 0.00 & 0.02 & 0.00 & 0.03 & 0.00 \\
\hline $\mathrm{Fe}_{2} \mathrm{O}_{3}$ & 0.54 & 1.37 & 2.77 & 3.14 & 3.14 & 2.23 & 2.87 \\
\hline $\mathrm{FeO}$ & 24.94 & 25.43 & 24.00 & 23.95 & 23.93 & 25.44 & 25.69 \\
\hline $\mathrm{MnO}$ & 1.98 & 2.15 & 1.37 & 1.51 & 2.25 & 2.17 & 2.11 \\
\hline $\mathrm{MgO}$ & 10.64 & 9.78 & 11.05 & 10.60 & 10.20 & 9.46 & 9.23 \\
\hline $\mathrm{CaO}$ & 0.75 & 0.82 & 0.70 & 1.14 & 0.83 & 1.13 & 1.20 \\
\hline $\mathrm{Na}_{2} \mathrm{O}$ & 0.02 & 0.03 & 0.02 & 0.01 & 0.05 & 0.03 & 0.00 \\
\hline $\mathrm{K}_{2} \mathrm{O}$ & 0.00 & 0.01 & 0.01 & 0.00 & 0.00 & 0.01 & 0.00 \\
\hline Total & 100.6 & 100.2 & 100.7 & 101.2 & 100.9 & 101.3 & 101.6 \\
\hline 0 & 12.000 & 12.000 & 12.000 & 12.000 & 12.000 & 12.000 & 12.000 \\
\hline $\mathrm{Si}$ & 2.977 & 2.972 & 2.923 & 2.910 & 2.909 & 2.936 & 2.923 \\
\hline $\mathrm{Ti}$ & 0.007 & 0.002 & 0.002 & 0.000 & 0.002 & 0.002 & 0.001 \\
\hline $\mathrm{Al}$ & 2.005 & 1.980 & 1.994 & 2.002 & 2.005 & 2.000 & 1.990 \\
\hline $\mathrm{Cr}$ & 0.000 & 0.000 & 0.000 & 0.001 & 0.000 & 0.001 & 0.000 \\
\hline $\mathrm{Fe}^{3+}$ & 0.031 & 0.079 & 0.158 & 0.179 & 0.180 & 0.128 & 0.164 \\
\hline $\mathrm{Fe}^{2+}$ & 1.584 & 1.634 & 1.524 & 1.518 & 1.524 & 1.620 & 1.638 \\
\hline Mn & 0.128 & 0.140 & 0.088 & 0.097 & 0.145 & 0.140 & 0.136 \\
\hline $\mathrm{Mg}$ & 1.205 & 1.120 & 1.250 & 1.198 & 1.158 & 1.071 & 1.049 \\
\hline $\mathrm{Ca}$ & 0.061 & 0.068 & 0.057 & 0.093 & 0.068 & 0.093 & 0.099 \\
\hline $\mathrm{Na}$ & 0.002 & 0.004 & 0.002 & 0.002 & 0.007 & 0.004 & 0.000 \\
\hline K & 0.001 & 0.001 & 0.001 & 0.000 & 0.000 & 0.001 & 0.000 \\
\hline Sum & 8.001 & 8.000 & 7.999 & 8.000 & 7.998 & 7.996 & 8.000 \\
\hline $\mathrm{X}_{\mathrm{Mg}}\left(\mathrm{Fe}^{2+}\right)$ & 0.432 & 0.407 & 0.451 & 0.441 & 0.432 & 0.399 & 0.390 \\
\hline $\mathrm{X}_{\mathrm{Fe}}$ & 0.531 & 0.551 & 0.522 & 0.522 & 0.535 & 0.553 & 0.561 \\
\hline Almandine & 0.529 & 0.538 & 0.505 & 0.505 & 0.507 & 0.538 & 0.541 \\
\hline Pyrope & 0.403 & 0.370 & 0.416 & 0.401 & 0.388 & 0.359 & 0.350 \\
\hline Spessartine & 0.045 & 0.050 & 0.039 & 0.044 & 0.060 & 0.055 & 0.054 \\
\hline Grossular & 0.023 & 0.026 & 0.029 & 0.042 & 0.035 & 0.039 & 0.042 \\
\hline Andradite & 0.000 & 0.001 & 0.001 & 0.002 & 0.002 & 0.001 & 0.002 \\
\hline
\end{tabular}

SprGr-Sapphirine-bearing granulite; La-Layer; Bo-Boudin; D III-Domain III; Charno-charnockite; c-core; r-rim.

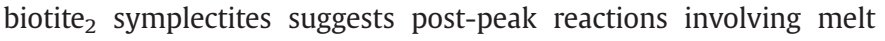
(Stevens and Clemens, 1993). The topological relations of these phases (Fig. 10c, d) allow us to propose that these symplectites were formed via the following di- or multi-variant KFMASH reactions:

$\mathrm{Grt}+\mathrm{Kfs}+\mathrm{L} \Rightarrow(\mathrm{Crd}+\mathrm{Qtz})_{\text {symplectite }}+\left(\mathrm{Crd}+\mathrm{Bt}_{2}\right)_{\text {symplectite }}$

$\mathrm{Opx}_{1}+\mathrm{Kfs}+\mathrm{L} \Rightarrow\left(\mathrm{Crd}+\mathrm{Bt}_{2}\right)_{\text {symplectite }}+(\mathrm{Crd}+\mathrm{Qtz})_{\text {symplectite }}$

The calculated $P-T$ pseudosection in the KFMASH system for the Domain III (Fig. 11b) predicts that cordierite-biotite ${ }_{2}$-quartz symplectites are produced at the expense of orthopyroxene during cooling at temperatures lower than $860{ }^{\circ} \mathrm{C}$. The resulting equilibrium is:

$\mathrm{Grt}+\mathrm{Crd}+\mathrm{Bt}_{2}+\mathrm{Qtz}+L+\mathrm{Kfs}$ (assemblage 4, v = 3)

Reaction (8) and assemblage (4) suggest that the consumption of orthopyrtoxene $_{1}$ occurred in the presence of melt. In contrast, cordierite+orthopyroxene $e_{2}$ symplectites at the expense of garnet and orthopyroxene ${ }_{1}$ (Fig. 6a, b) could have been produced through a divariant melt-absent FMAS reaction (Fig. 10e):

$\mathrm{Grt}+\mathrm{Opx}_{1} \Rightarrow \mathrm{Crd}+\mathrm{Opx}_{2}$
The occurrence of magnetite exsolution in host orthopyroxene 2 $\left(\mathrm{Opx}_{2}^{*}\right)$, always in close association to spinel $_{2}+$ cordierite + magnetite and orthopyroxene $_{2}+$ cordierite symplectites (Fig. $6 \mathrm{a}, \mathrm{b}$ ) can also be related to cooling. This interpretation is supported by the fact that orthopyroxene $_{2} *$ is less aluminous and magnesian than orthopyroxene ${ }_{1}$.

7.2. Role of variations in $\mathrm{P}-\mathrm{T}$ conditions and $\mathrm{SiO}_{2}$ bulk composition on the evolution of silica-undersaturated sapphirine-bearing assemblages

The estimation of maximum preserved $P-T$ conditions using classic geothermobarometry (reverse modelling) based on cation exchange and/or net transfer reactions is subject to uncertainties since elemental equilibrium between the rock-forming minerals is rarely preserved upon cooling (Frost and Chacko, 1989; Pattison et al., 2003).

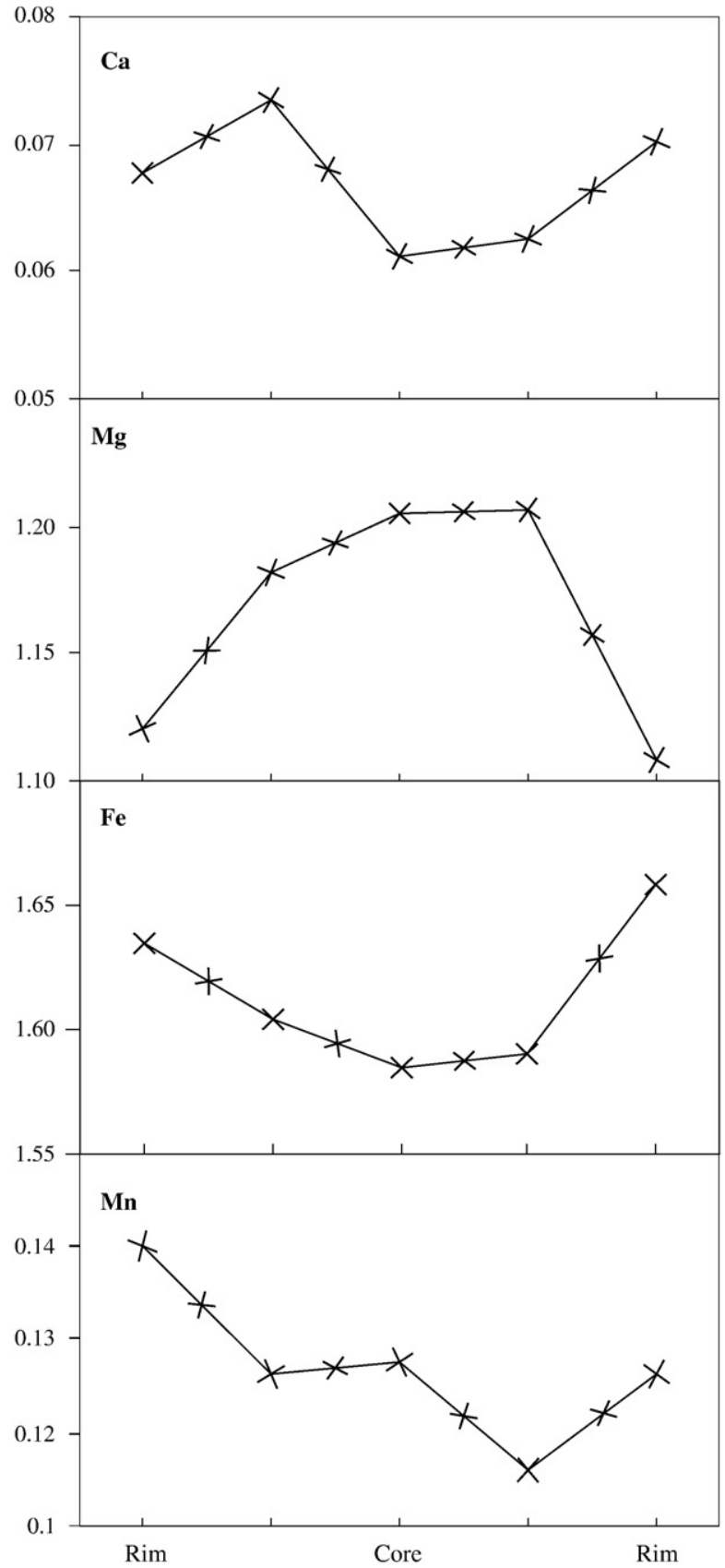

Fig. 8. Compositional variations along the profile in the garnet porphyroblast of $155 \mathrm{C} 4$ sapphirine-bearing granulite sample. 
This limitation has been overcome somewhat by retrieval techniques that are based on the Al content of orthopyroxene (Harley and Green, 1982; Harley, 1984; Hensen and Harley, 1990) and on the readjustment of $\mathrm{Fe}-\mathrm{Mg}$ mineral compositions to converge in $P-T$ space with $y$ (opx) (Pattison and Bégin, 1994; Fitzsimons and Harley, 1994; Pattison et al., 2003). Estimation of peak P-T conditions using calculated phase diagrams (forward modeling) reduces uncertainties since the stability field of the peak mineral assemblage is defined (Kelsey et al., 2003b). To estimate the $P$-T conditions and the evolution of mineral assemblages we have combined both approaches: reverse and forward modelling.

The pseudosection calculated for Domain I (Fig. 11a) show that sapphirine-bearing mineral assemblages without garnet and in the presence of melt can occur at temperatures as high as $1050{ }^{\circ} \mathrm{C}$. The crystallization of cordierite in this assemblage limits the pressure to less than $8.0 \mathrm{kbar}$ at a temperature close to $930{ }^{\circ} \mathrm{C}$. Sub-solidus assemblages are stable at $P-T$ conditions lower than $7.5 \mathrm{kbar}$ and $930{ }^{\circ} \mathrm{C}$.

In the Domain II, the fact that the mineral assemblage has coexisting orthopyroxene + sillimanite suggests minimum $P-T$ conditions of 8.0-9.0 kbar and $900{ }^{\circ} \mathrm{C}$ in KFMASH system (Kelsey et al., 2003b).

The pseudosection calculated for Domain III (Fig. 11b) show that garnet-cordierite-bearing mineral assemblages without sapphirine but with quartz and melt present are stable at pressures lower than $8.5 \mathrm{kbar}$ and temperatures ranging from $1050{ }^{\circ} \mathrm{C}$ to $860{ }^{\circ} \mathrm{C}$. This pseudosection also suggests that the formation of quartz-biotitecordierite symplectites as well as the crystallization of K-feldspar would occur at $P-T$ conditions lower than 8.0 kbar and $860{ }^{\circ} \mathrm{C}$.

$P-T$ conditions estimated via reverse modeling based on the regression method of Pattison and Bégin (1994) have been possible on Domain III and the garnet-bearing portion of the charnockite. This method retrieves close-to-peak mineral compositions from which close-to-peak pressure and temperature estimates are obtained with the Al-orthopyroxene-garnet barometer of Harley and Green (1982) and the garnet-orthopyroxene geothermometer of Harley (1984), respectively. Garnet and orthopyroxene ${ }_{1}$ core compositions have been used for calculations of $P-T$ conditions following the protocol of Pattison and Bégin (1994). The results obtained on the Domain III (155C5) and in the charnockite (155E) samples are similar (Table 11). In the Domain III of the sapphirine-bearing granulite the calculated $P$ is $8.5 \pm 2.0 \mathrm{kbar}$ that leads to a retrieved $T$ of $950 \pm 40-60{ }^{\circ} \mathrm{C}$ while in charnockite $P-T$ conditions are $8.0 \pm 2.0$ kbar and $945 \pm 40-60{ }^{\circ} \mathrm{C}$. The errors are after Harley (1984) who assumes \pm 0.1 as the maximum error in the calculated $K_{\mathrm{D}}$.

The results from the calculated pseudosections and the retrieval technique support the mineralogical evidence (i.e. opx + sill and spr + opx) for ultrahigh temperature (UHT) metamorphic conditions (Harley, 1998). Other features also indicate that UHT conditions prevailed during peak metamorphism: (1) $\mathrm{Al}_{2} \mathrm{O}_{3}$ content greater than $10.0 \mathrm{wt} . \%$ and $\mathrm{TiO}_{2}$ close to $5.0 \mathrm{wt} . \%$ in orthopyroxene and biotite porphyroblasts, respectively (Harley, 1998; Mouri et al., 1996); and (2) low volatile content in cordierite which according to the experimental work of Carrington and Harley (1996) indicates temperatures in excess of $900{ }^{\circ} \mathrm{C}$.

The sequence of mineral assemblages (1), (2) and (3) in Domain I and the crystallization of cordierite-quartz and cordierite-biotite ${ }_{2}$ symplectites in Domain III are consistent with a near-isobaric retrograde path trajectory (Fig. 11a, b) with thermal peak conditions in excess of $930^{\circ} \mathrm{C}$.

$P-T$ pseudosections for silica-undersaturated rocks in a KFMASH system is also characterized by multi-variant equilibria highly sensitive to bulk silica composition (e.g. White et al., 2002; Kelsey et al., 2003b, 2004, 2005; White et al., 2007). In order to investigate

Table 6

Representative cordierite analyses

\begin{tabular}{|c|c|c|c|c|c|c|c|c|}
\hline \multirow{3}{*}{$\begin{array}{l}\text { Sample/ } \\
\text { rock }\end{array}$} & 155 & $155 B$ & $155 \mathrm{~A}$ & $155 C 4$ & $155 C 5$ & $155 C 4$ & $155 C 4$ & $155 \mathrm{C} 5$ \\
\hline & SprGr La & SprGr Bo & SprGr La & SprGr La & SprGr Bo & SprGr La & SprGr La & SprGr Bo \\
\hline & D I & D I & D II & D II & D II & D III & D III & D III \\
\hline Position & $\mathrm{A} 38 \mathrm{R}_{\mathrm{spr}}$ & $\mathrm{A} 10 \mathrm{R}_{\mathrm{opx}}$ & $\mathrm{A} 33 \mathrm{G}_{\mathrm{spr}}$ & $A 52 S_{s p l}$ & $\mathrm{~A} 58 \mathrm{~S}_{\mathrm{spl}}$ & $\mathrm{A} 40 \mathrm{~S}_{\mathrm{opx}}$ & $\mathrm{A} 21 \mathrm{~S}_{\mathrm{qtz}}$ & $\mathrm{A} 45 \mathrm{~S}_{\mathrm{bt}}$ \\
\hline$\overline{\mathrm{SiO}_{2}}$ & 50.50 & 49.46 & 49.73 & 49.65 & 50.00 & 49.93 & 49.56 & 49.51 \\
\hline $\mathrm{TiO}_{2}$ & 0.00 & 0.00 & 0.00 & 0.01 & 0.01 & 0.00 & 0.06 & 0.00 \\
\hline $\mathrm{Al}_{2} \mathrm{O}_{3}$ & 33.81 & 33.52 & 33.69 & 33.88 & 33.97 & 33.52 & 33.36 & 33.74 \\
\hline $\mathrm{Cr}_{2} \mathrm{O}_{3}$ & 0.00 & 0.00 & 0.00 & 0.00 & 0.02 & 0.01 & 0.02 & 0.00 \\
\hline $\mathrm{FeO}$ & 3.21 & 3.46 & 3.11 & 3.58 & 3.66 & 3.47 & 4.10 & 3.97 \\
\hline $\mathrm{MnO}$ & 0.03 & 0.07 & 0.03 & 0.15 & 0.11 & 0.08 & 0.12 & 0.10 \\
\hline MgO & 11.88 & 11.48 & 11.77 & 11.42 & 11.47 & 11.68 & 11.13 & 11.39 \\
\hline $\mathrm{CaO}$ & 0.00 & 0.00 & 0.00 & 0.04 & 0.01 & 0.02 & 0.06 & 0.00 \\
\hline $\mathrm{Na}_{2} \mathrm{O}$ & 0.03 & 0.00 & 0.07 & 0.08 & 0.05 & 0.07 & 0.02 & 0.06 \\
\hline $\mathrm{K}_{2} \mathrm{O}$ & 0.03 & 0.00 & 0.01 & 0.04 & 0.02 & 0.00 & 0.00 & 0.00 \\
\hline Total & 99.49 & 97.99 & 98.41 & 98.85 & 99.32 & 98.78 & 98.43 & 98.78 \\
\hline 0 & 18.000 & 18.000 & 18.000 & 18.000 & 18.000 & 18.000 & 18.000 & 18.000 \\
\hline $\mathrm{Si}$ & 5.016 & 4.994 & 4.994 & 4.980 & 4.989 & 5.005 & 5.001 & 4.976 \\
\hline $\mathrm{Ti}$ & 0.000 & 0.000 & 0.000 & 0.001 & 0.001 & 0.000 & 0.004 & 0.000 \\
\hline $\mathrm{Al}$ & 3.957 & 3.989 & 3.986 & 4.004 & 3.995 & 3.959 & 3.967 & 3.996 \\
\hline $\mathrm{Cr}$ & 0.000 & 0.000 & 0.000 & 0.000 & 0.001 & 0.001 & 0.001 & 0.000 \\
\hline $\mathrm{Fe}^{2+}$ & 0.266 & 0.292 & 0.261 & 0.300 & 0.305 & 0.291 & 0.346 & 0.333 \\
\hline $\mathrm{Mn}$ & 0.002 & 0.006 & 0.002 & 0.013 & 0.009 & 0.007 & 0.010 & 0.009 \\
\hline $\mathrm{Mg}$ & 1.759 & 1.728 & 1.762 & 1.707 & 1.706 & 1.745 & 1.674 & 1.706 \\
\hline $\mathrm{Ca}$ & 0.000 & 0.000 & 0.000 & 0.004 & 0.001 & 0.002 & 0.006 & 0.000 \\
\hline $\mathrm{Na}$ & 0.006 & 0.000 & 0.013 & 0.015 & 0.009 & 0.013 & 0.004 & 0.011 \\
\hline K & 0.004 & 0.001 & 0.001 & 0.005 & 0.002 & 0.001 & 0.000 & 0.000 \\
\hline Sum & 11.010 & 11.009 & 11.019 & 11.029 & 11.018 & 11.024 & 11.013 & 11.032 \\
\hline $\mathrm{X}_{\mathrm{Mg}}\left(\mathrm{Fe}^{2+}\right)$ & 0.868 & 0.855 & 0.871 & 0.851 & 0.848 & 0.857 & 0.829 & 0.836 \\
\hline $\mathrm{X}_{\mathrm{Fe}}$ & 0.131 & 0.144 & 0.131 & 0.148 & 0.152 & 0.142 & 0.170 & 0.163 \\
\hline
\end{tabular}

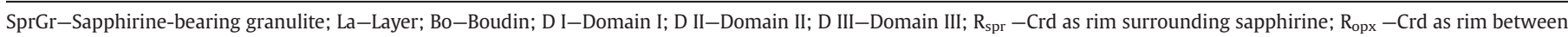

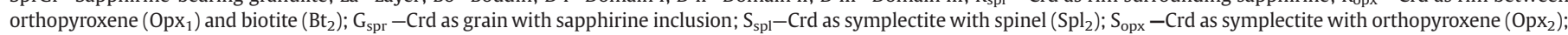
$\mathrm{S}_{\mathrm{qtz}}-$ Crd as symplectite with quartz; $\mathrm{S}_{\mathrm{bt}}-$ Crd as symplectite with biotite $\left(\mathrm{Bt}_{2}\right)$. 

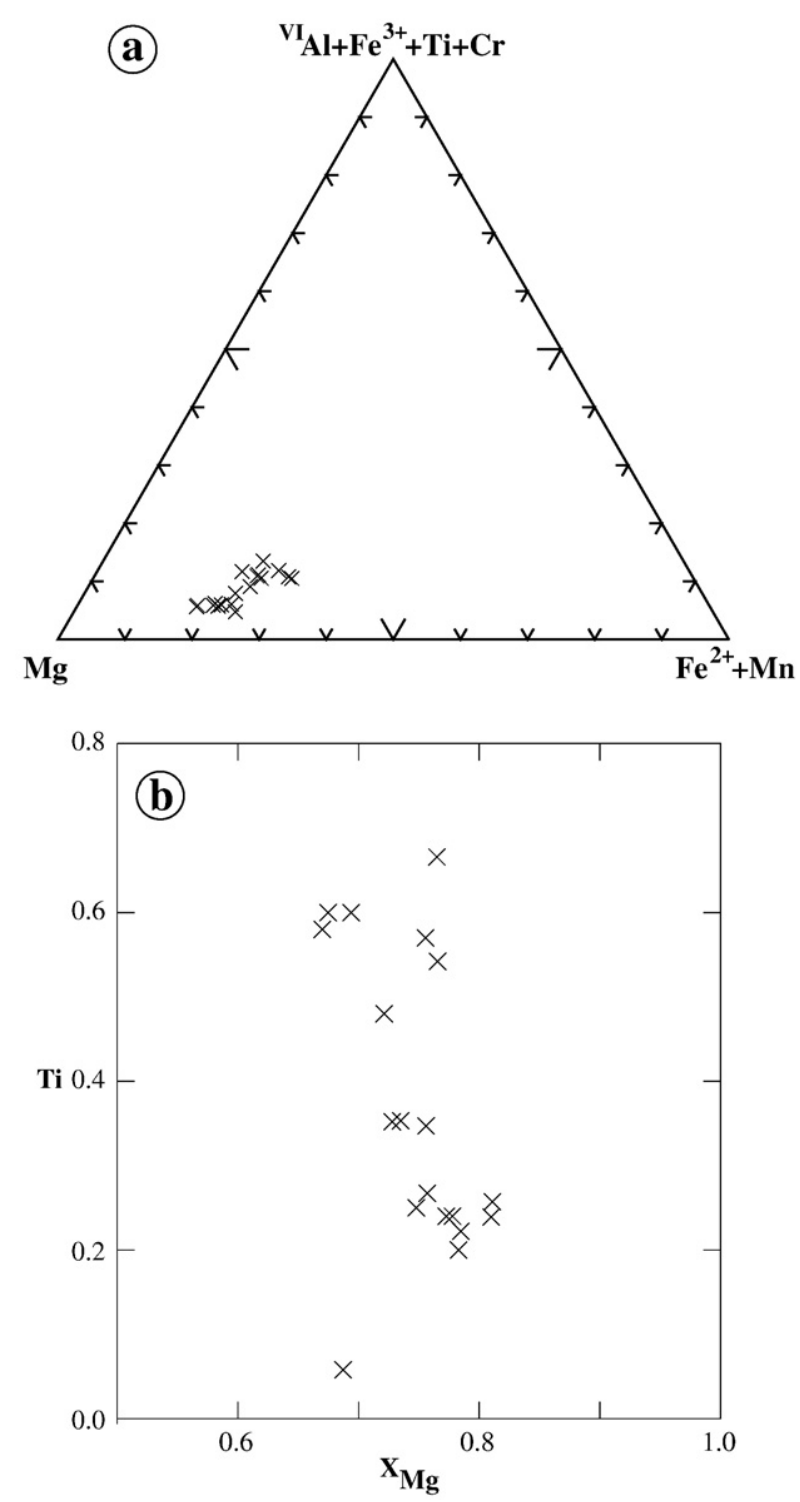

Fig. 9. Compositional plots of biotite: (a) Ternary diagram ${ }^{\mathrm{VI}} \mathrm{Al}+\mathrm{Fe}^{+3}+\mathrm{Ti}+\mathrm{Cr}-\mathrm{Mg}-\mathrm{Fe}^{+2}+\mathrm{Mn}$ (a.p.f.u for 22 oxygens) to show phlogopite component enrichment; (b) Ti vs $\mathrm{X}_{\mathrm{Mg}}$ (a.p.f.u for 22 oxygens) to show negative correlation.

the effects of silica introduction into the sapphirine-bearing layer or boudin from the hosting charnockite we have calculated a $T-\mathrm{M}\left(\mathrm{SiO}_{2}\right)$ pseudosection at a fixed pressure of $8.0 \mathrm{kbar}$ on the basis of the M1 bulk composition. In Fig. $11 \mathrm{c}, \mathrm{M}\left(\mathrm{SiO}_{2}\right)$ is the mole percent amount of silica expressed as a normalized value ranging between 0 and 1 . The Domain I has a $\mathrm{M}\left(\mathrm{SiO}_{2}\right)$ value of 0.24 . Fig. 11c shows that for $\mathrm{M}\left(\mathrm{SiO}_{2}\right)$ lower than 0.05 and for a large interval of $T\left(850-1050{ }^{\circ} \mathrm{C}\right)$, the stable assemblage consists of $\mathrm{Bt}+\mathrm{Spl}+\mathrm{Opx}+\mathrm{Kfs}$. This assemblage is consistent with the pre-peak assemblage defined in Domain I (i.e. $\mathrm{Opx}_{1}+$ $\mathrm{Spl}_{1 \mathrm{i}}+\mathrm{Bt}_{1 \mathrm{i}}$ ). An increase of $\mathrm{SiO}_{2}$ content at constant pressure and temperature has the direct consequence of crystallizing sapphirine at the expense of spinel with production of the peak assemblage $\mathrm{Bt}_{1}+$ $\mathrm{Opx}_{1}+\mathrm{Spr}+\mathrm{Kfs}+\mathrm{L}$. This assemblage is stable over a large range of $\mathrm{M}$ $\left(\mathrm{SiO}_{2}\right)$ (0.07 to $\left.\sim 0.45\right)$ at temperatures greater than $910{ }^{\circ} \mathrm{C}$. The crystallization of late cordierite can either be produced by a continuous increase in silica content at constant $P-T$ conditions or by an isobaric and isochemical cooling down to $910{ }^{\circ} \mathrm{C}$ (Fig. 11c). Here, we favor the cooling hypothesis because the minimum amount of $\mathrm{SiO}_{2}$ required to produce cordierite $\left(\mathrm{MSiO}_{2}=0.7\right.$ at $\left.910{ }^{\circ} \mathrm{C}\right)$ at constant $P-T$ conditions is inconsistent with analytical data in Domain I (Table 9).

\section{Geochronology of the UHT metamorphism}

The U-Th-Pb electron microprobe (EMP) method of monazite dating (Montel et al., 1996) has been used to constrain the timing of the mineral assemblages. The in-situ nature and the high spatial resolution of the technique allow dating of grains in their petrographical context, therefore combining geochronological information with the metamorphic petrology (Kelsey et al., 2003a; Goncalves et al., 2003; Santosh et al., 2003; Goncalves et al., 2004; Mahan et al., 2006; Santosh et al., 2006).

Monazite compositions (Table 12) from sapphirine-bearing granulite (sample 155) and charnockite (sample 155E) were obtained on the same Cameca SX100 electron microprobe used for analysing the mineral compositions. The analytical conditions and the used standards are the same as those described by Goncalves et al. (2004). The theoretical basis and associated statistical treatment of data follow the procedure detailed by Montel et al. (1996), Braun et al. (1998) and Goncalves et al. (2004).

Monazite grains have diameters varying from 20 to $100 \mu \mathrm{m}$ and can occur as inclusions in sapphirine (Fig. 12a, b), biotite (Fig. 12c, d), orthopyroxene (Fig. 12e, f), cordierite (Fig. 12g, h) and K-feldspar. Backscattered electron imaging did not reveal significant zoning but it does not preclude that some grains can be chemically zoned. Monazite is richer in $\mathrm{P}$ and in REE in the charnockite whereas in the sapphirinebearing granulite monazite is richer in $\mathrm{Si}, \mathrm{U}, \mathrm{Th}, \mathrm{Pb}$ and $\mathrm{Ca}$ (Table 11 ) and this is reflected in the higher $\mathrm{Pb} /(\mathrm{Th}+\mathrm{U})$ ratios for monazite in the charnockite (Table 12).

Twenty-two measurements carried out mainly on monazite included in cordierite were selected for the sapphirine-bearing granulite and twenty measurements were selected for the charnockite on grains included in orthopyroxene and biotite. The calculated ages are $2057 \pm 17$ Ma for monazite in sapphirine-bearing granulite (Fig. 13a) and 2080 \pm 26 Ma for monazite in charnockite (Fig. 13b). Taking into account the uncertainties, we suggest that these two ages represent a single event that corresponds to the emplacement of the charnockite intrusion and the UHT metamorphism and melt/rock interactions recorded by the sapphirine-bearing enclaves. These ages are in good agreement with (1) SHRIMP ages of the granulite metamorphism in plutonic rocks of the Caraíba Complex $(2072 \pm 17$ / 22 Ma after Silva et al., 1997, 2002) and (2) monazite in-situ ages for peraluminous magmatism (2080 $\pm 15 \mathrm{Ma}$ after Leite, 2002) in the area.

\section{Discussion}

9.1. UHT metamorphism: regional and global implications for the assembly of Paleoproterozoic continents

The Salvador-Curaçá Belt (SCB) is recognized as a granulite terrane involved in the oblique collision of Archean blocks at c. 2.0-2.1 Ga (Ledru et al., 1994; Sabaté, 1996; Barbosa and Sabaté, 2002, 2004). The resultant crustal thickening is considered as the driving force for the metamorphism (Ledru et al., 1994; Barbosa and Sabaté, 2002, 2004). High-grade metamorphism throughout the belt is estimated at pressures up to $7.0 \mathrm{kbar}$ and temperatures around $850{ }^{\circ} \mathrm{C}$ (Barbosa and Sabaté, 2002, 2004). However sapphirine-bearing granulites, with the same mineralogical features as the one described in this contribution, have been recognized in two other localities (Fujimori and Allard, 1966; Stormer, 1973; Fujimori, 1985; Ackermand et al., 1987), suggesting that UHT metamorphism might be widespread in SCB. This implies that a heat source additional to crustal thickening and accretion of radioactive material would be necessary to cause the extreme crustal perturbation (Harley, 1989). We suggest that pulses of charnockitic magma emplacement promoted the documented UHT 
Table 7

Representative biotite analyses

\begin{tabular}{|c|c|c|c|c|c|c|c|c|c|c|}
\hline \multirow{4}{*}{$\begin{array}{l}\text { Sample/ } \\
\text { rock }\end{array}$} & 155 & $155 B$ & $155 B$ & $155 A$ & $155 \mathrm{~A}$ & $155 C 4$ & $155 C 4$ & $155 \mathrm{C} 5$ & $155 \mathrm{E}$ & $155 \mathrm{E}$ \\
\hline & SprGr & SprGr & SprGr & SprGr & SprGr & SprGr & SprGr & SprGr & Charno & Charno \\
\hline & La & Bo & Bo & La & $\mathrm{La}$ & $\mathrm{La}$ & $\mathrm{La}$ & Bo & & \\
\hline & D I & D I & D I & D II & D II & D II & D III & D III & & \\
\hline Position & A8cI & $\mathrm{A} 7 \mathrm{cP}$ & A6rP & $\mathrm{A} 8 \mathrm{cP}$ & A9rP & $\mathrm{A} 12 \mathrm{cI}$ & A15cI & A09cS & $\mathrm{A} 13 \mathrm{cP}$ & $\mathrm{A} 14 \mathrm{rP}$ \\
\hline $\mathrm{SiO}_{2}$ & 37.22 & 38.20 & 38.40 & 37.95 & 37.41 & 36.77 & 37.09 & 36.40 & 37.05 & 36.64 \\
\hline $\mathrm{TiO}_{2}$ & 3.10 & 2.08 & 2.28 & 2.21 & 2.34 & 5.25 & 5.54 & 4.15 & 4.55 & 4.95 \\
\hline $\mathrm{Al}_{2} \mathrm{O}_{3}$ & 16.15 & 16.06 & 15.92 & 15.49 & 15.09 & 15.34 & 15.23 & 15.58 & 16.08 & 15.92 \\
\hline $\mathrm{FeO}$ & 10.24 & 9.46 & 9.60 & 8.26 & 8.23 & 12.31 & 12.78 & 13.42 & 12.07 & 13.09 \\
\hline $\mathrm{MnO}$ & 0.01 & 0.03 & 0.00 & 0.03 & 0.00 & 0.03 & 0.02 & 0.03 & 0.00 & 0.03 \\
\hline $\mathrm{MgO}$ & 17.70 & 19.10 & 19.09 & 19.76 & 19.77 & 15.19 & 15.18 & 15.55 & 17.14 & 15.95 \\
\hline $\mathrm{CaO}$ & 0.00 & 0.00 & 0.00 & 0.00 & 0.03 & 0.02 & 0.01 & 0.00 & 0.00 & 0.01 \\
\hline $\mathrm{Na}_{2} \mathrm{O}$ & 0.16 & 0.20 & 0.16 & 0.18 & 0.17 & 0.11 & 0.09 & 0.06 & 0.04 & 0.06 \\
\hline $\mathrm{K}_{2} \mathrm{O}$ & 10.40 & 10.30 & 10.10 & 10.38 & 10.33 & 9.93 & 10.03 & 9.95 & 10.32 & 10.33 \\
\hline $\mathrm{F}$ & 1.51 & 2.06 & 1.90 & 2.00 & 1.62 & 1.15 & 1.39 & 0.54 & 0.30 & 0.48 \\
\hline Total & 96.49 & 97.49 & 97.45 & 96.26 & 94.96 & 96.10 & 97.36 & 95.68 & 97.54 & 97.45 \\
\hline 0 & 22.000 & 22.000 & 22.000 & 22.000 & 22.000 & 22.000 & 22.000 & 22.000 & 22.000 & 22.000 \\
\hline $\mathrm{Si}$ & 5.396 & 5.446 & 5.470 & 5.459 & 5.463 & 5.401 & 5.388 & 5.406 & 5.301 & 5.289 \\
\hline $\mathrm{Ti}$ & 0.337 & 0.223 & 0.244 & 0.239 & 0.257 & 0.580 & 0.605 & 0.463 & 0.489 & 0.537 \\
\hline $\mathrm{Al}$ & 2.759 & 2.697 & 2.672 & 2.626 & 2.595 & 2.655 & 2.607 & 2.727 & 2.710 & 2.709 \\
\hline $\mathrm{Fe}^{2+}$ & 1.241 & 1.128 & 1.143 & 0.994 & 1.005 & 1.512 & 1.552 & 1.667 & 1.355 & 1.492 \\
\hline $\mathrm{Mn}$ & 0.002 & 0.004 & 0.000 & 0.003 & 0.000 & 0.003 & 0.002 & 0.003 & 0.000 & 0.004 \\
\hline $\mathrm{Mg}$ & 3.825 & 4.056 & 4.054 & 4.236 & 4.301 & 3.324 & 3.286 & 3.443 & 3.655 & 3.431 \\
\hline $\mathrm{Ca}$ & 0.000 & 0.000 & 0.000 & 0.000 & 0.004 & 0.002 & 0.001 & 0.000 & 0.000 & 0.001 \\
\hline $\mathrm{Na}$ & 0.043 & 0.055 & 0.044 & 0.052 & 0.047 & 0.032 & 0.024 & 0.018 & 0.011 & 0.016 \\
\hline K & 1.923 & 1.873 & 1.835 & 1.905 & 1.925 & 1.861 & 1.858 & 1.884 & 1.883 & 1.902 \\
\hline $\mathrm{F}$ & 0.689 & 0.929 & 0.858 & 0.910 & 0.746 & 0.536 & 0.640 & 0.255 & 0.137 & 0.217 \\
\hline Sum & 16.215 & 16.411 & 16.319 & 16.424 & 16.343 & 15.906 & 15.963 & 15.866 & 15.541 & 15.598 \\
\hline $\mathrm{X}_{\mathrm{Mg}}\left(\mathrm{Fe}^{2}\right)$ & 0.755 & 0.782 & 0.780 & 0.810 & 0.811 & 0.687 & 0.679 & 0.674 & 0.729 & 0.697 \\
\hline $\mathrm{X}_{\mathrm{Fe}}$ & 0.245 & 0.217 & 0.220 & 0.190 & 0.189 & 0.312 & 0.321 & 0.326 & 0.270 & 0.303 \\
\hline
\end{tabular}

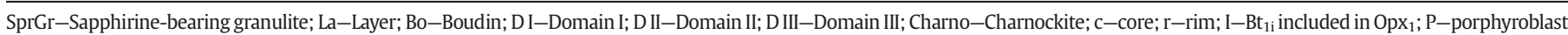
$\left(\mathrm{Bt}_{1}\right) ; \mathrm{S}-\mathrm{Bt}_{2}$ as symplectite with quartz or cordierite.

Table 8

Representative feldspar analyses

\begin{tabular}{|c|c|c|c|c|c|c|c|c|c|}
\hline \multirow{4}{*}{$\begin{array}{l}\text { Sample/ } \\
\text { rock }\end{array}$} & $155 \mathrm{~A}$ & $155 \mathrm{~A}$ & $155 \mathrm{C} 5$ & $155 \mathrm{C} 5$ & $155 C 5$ & $155 \mathrm{E}$ & $155 \mathrm{E}$ & $155 \mathrm{E}$ & $155 \mathrm{E}$ \\
\hline & SprGr & SprGr & SprGr & SprGr & SprGr & Charno & Charno & Charno & Charno \\
\hline & La & La & Bo & Bo & Bo & & & & \\
\hline & D II & D II & D II & D II & D III & & & & \\
\hline Position & $01 \mathrm{cPl}$ & 02rPl & $16 \mathrm{hPt}$ & $15 \mathrm{ePt}$ & $35 \mathrm{cOrt}$ & 76hAPt & 75eAPt & $40 \mathrm{cPl}$ & 39rPl \\
\hline $\mathrm{SiO}_{2}$ & 62.32 & 62.20 & 64.01 & 62.74 & 63.97 & 61.53 & 63.53 & 59.63 & 61.17 \\
\hline $\mathrm{TiO}_{2}$ & 0.03 & 0.02 & 0.03 & 0.05 & 0.06 & 0.02 & 0.03 & 0.00 & 0.02 \\
\hline $\mathrm{Al}_{2} \mathrm{O}_{3}$ & 23.26 & 23.39 & 18.45 & 23.41 & 18.53 & 24.35 & 18.54 & 23.24 & 23.76 \\
\hline $\mathrm{Cr}_{2} \mathrm{O}_{3}$ & 0.00 & 0.03 & 0.00 & 0.02 & 0.03 & 0.07 & 0.00 & 0.00 & 0.01 \\
\hline $\mathrm{FeO}$ & 0.06 & 0.10 & 0.00 & 0.00 & 0.09 & 0.08 & 0.00 & 2.36 & 0.06 \\
\hline $\mathrm{MnO}$ & 0.02 & 0.00 & 0.04 & 0.00 & 0.01 & 0.00 & 0.02 & 0.25 & 0.01 \\
\hline MgO & 0.02 & 0.00 & 0.02 & 0.00 & 0.00 & 0.01 & 0.00 & 0.88 & 0.00 \\
\hline $\mathrm{CaO}$ & 4.91 & 5.43 & 0.10 & 5.08 & 0.10 & 5.80 & 0.01 & 5.21 & 5.37 \\
\hline $\mathrm{Na}_{2} \mathrm{O}$ & 8.45 & 8.53 & 0.83 & 8.60 & 1.22 & 8.33 & 0.63 & 7.77 & 8.73 \\
\hline $\mathrm{K}_{2} \mathrm{O}$ & 0.45 & 0.43 & 15.52 & 0.15 & 15.10 & 0.23 & 15.73 & 0.18 & 0.32 \\
\hline Total & 99.51 & 100.1 & 99.00 & 100.1 & 99.11 & 100.4 & 98.50 & 99.53 & 99.44 \\
\hline 0 & 8.000 & 8.000 & 8.000 & 8.000 & 8.000 & 8.000 & 8.000 & 8.000 & 8.000 \\
\hline $\mathrm{Si}$ & 2.781 & 2.756 & 2.981 & 2.784 & 2.970 & 2.722 & 2.976 & 2.681 & 2.723 \\
\hline $\mathrm{Ti}$ & 0.001 & 0.001 & 0.001 & 0.002 & 0.002 & 0.001 & 0.001 & 0.000 & 0.001 \\
\hline $\mathrm{Al}$ & 1.223 & 1.222 & 1.013 & 1.224 & 1.014 & 1.270 & 1.024 & 1.232 & 1.246 \\
\hline $\mathrm{Cr}$ & 0.000 & 0.001 & 0.000 & 0.001 & 0.001 & 0.002 & 0.000 & 0.000 & 0.000 \\
\hline $\mathrm{Fe}^{2+}$ & 0.002 & 0.003 & 0.000 & 0.000 & 0.003 & 0.003 & 0.000 & 0.080 & 0.002 \\
\hline $\mathrm{Mn}$ & 0.001 & 0.000 & 0.002 & 0.000 & 0.000 & 0.000 & 0.001 & 0.010 & 0.000 \\
\hline $\mathrm{Mg}$ & 0.001 & 0.000 & 0.002 & 0.000 & 0.000 & 0.001 & 0.000 & 0.059 & 0.000 \\
\hline $\mathrm{Ca}$ & 0.235 & 0.258 & 0.005 & 0.241 & 0.005 & 0.275 & 0.001 & 0.251 & 0.260 \\
\hline $\mathrm{Na}$ & 0.731 & 0.733 & 0.075 & 0.740 & 0.110 & 0.714 & 0.058 & 0.678 & 0.754 \\
\hline K & 0.026 & 0.024 & 0.922 & 0.009 & 0.894 & 0.013 & 0.940 & 0.011 & 0.018 \\
\hline Sum & 5.001 & 4.998 & 5.001 & 5.001 & 4.999 & 5.001 & 5.001 & 5.002 & 5.004 \\
\hline An & 0.237 & 0.254 & 0.005 & 0.244 & 0.005 & 0.274 & 0.001 & 0.267 & 0.249 \\
\hline$A b$ & 0.737 & 0.722 & 0.075 & 0.747 & 0.109 & 0.713 & 0.058 & 0.721 & 0.733 \\
\hline Or & 0.026 & 0.024 & 0.920 & 0.009 & 0.886 & 0.013 & 0.942 & 0.011 & 0.018 \\
\hline
\end{tabular}

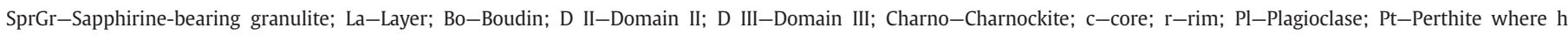
represents host phase and e exsolution lamella; Ort-Orthoclase in mesoperthite; APt-Antiperthite where h represents host phase and e exsolution lamella. 
evolution of the studied sapphirine-bearing granulite enclaves. Charnockitic magma of probable peraluminous affiliation (Table 9) could be generated by extensive anatexis of the lower continental crust. U-Pb SHRIMP ages of Paleoproterozoic mafic magmatism, related to the collision event, are reported in the northern and western part of SCB, outside the study area. They are constrained at $2085 \pm 5 / 9 \mathrm{Ma}$ (Oliveira et al., 2004) and are in good agreement with the ages obtained for the granulite metamorphism (Silva et al., 1997, 2002), peraluminous magmatism (Leite, 2002). The Paleoproterozoic mafic magmatism suggests that asthenospheric upwelling could provide the additional heat input to trigger mantle/lower crust anatexis and extreme crustal metamorphism (cf. Santosh et al., 2007; Santosh and Omori, 2008a,b). This could be achieved by detachment of the lithospheric thermal boundary layer after crustal thickening by orogenic collapse (cf. Harley, 1998) or slab break-off during collision (Davies and von Blanckenburg, 1995; von Blanckenburg and Davies, 1995).

The possible assembly of the 2.1-1.8 Ga Columbia supercontinent (Rogers and Santosh, 2002; Zhao et al., 2002, 2004; Hou et al., in press) has been correlated to orogenic belts with granulites that reached ultrahigh-metamorphic conditions (Brown, 2006, 2007; Santosh et al., 2007; Santosh and Omori, 2008a,b). These Paleoproterozoic granulites have been reported in North China Craton (Santosh et al., 2007), Taltson magmatic zone, northwestern Canada (Farquhar et al., 1996) and South Harris, Lewisian Complex, Scotland (Baba, 1999a,b; Hollis et al., 2006). This correlation implies a relationship between continent assembly and high geothermal gradients (Kelsey, 2008). Teixeira et al. (2007) proposed that the São Francisco Craton was one of the landmass that composed the Atlantica paleocontinent part (Rogers, 1996) of the Columbia supercontinent and Barbosa et al. (2006) demonstrated the presence of a UHT metamorphic occurrence in the Itabuna Belt (the southern part of the major Paleoproterozoic ItabunaSalvador-Curaçá Belt). Thus if there is a relationship between supercontinent assembly and UHT metamorphism, our work supports the hypothesis that the Salvador-Curaçá Belt would represent one of the orogens that contributed to the amalgamation of the Columbia supercontinent.

Table 9

Chemical analysis of major (wt.\%) and trace elements (ppm) for sapphirine-bearing granulite and charnockite

\begin{tabular}{|c|c|c|c|c|}
\hline \multirow[t]{3}{*}{ Sample/rock } & 155 & $155 \mathrm{~A}$ & $155 C 4$ & $155 \mathrm{E}$ \\
\hline & SprGr La & SprGr La & SprGr La & Charno \\
\hline & D I & D II & D III & \\
\hline $\mathrm{SiO}_{2}$ & 43.30 & 55.10 & 62.40 & 68.10 \\
\hline $\mathrm{TiO}_{2}$ & 0.93 & 0.44 & 0.96 & 0.80 \\
\hline $\mathrm{Al}_{2} \mathrm{O}_{3}$ & 21.70 & 16.60 & 16.30 & 14.10 \\
\hline $\mathrm{Fe}_{2} \mathrm{O}_{3}$ & 1.70 & 3.10 & 2.00 & 0.79 \\
\hline $\mathrm{FeO}$ & 8.50 & 6.50 & 5.10 & 6.00 \\
\hline $\mathrm{MnO}$ & 0.10 & 0.12 & 0.19 & 0.13 \\
\hline $\mathrm{MgO}$ & 14.50 & 10.20 & 5.40 & 3.00 \\
\hline $\mathrm{CaO}$ & 0.23 & 1.10 & 1.30 & 2.00 \\
\hline $\mathrm{Na}_{2} \mathrm{O}$ & 0.24 & 2.60 & 2.00 & 2.00 \\
\hline $\mathrm{K}_{2} \mathrm{O}$ & 6.70 & 3.10 & 2.95 & 1.50 \\
\hline $\mathrm{P}_{2} \mathrm{O}_{5}$ & 0.02 & 0.06 & 0.06 & 0.08 \\
\hline $\mathrm{H}_{2} \mathrm{O}^{+}$ & 1.00 & 0.56 & 0.65 & 0.51 \\
\hline $\mathrm{CO}_{2}$ & 0.59 & 0.72 & 0.85 & 1.30 \\
\hline Total & 99.51 & 100.20 & 100.16 & 100.31 \\
\hline Ba & 1103 & 1195 & 728 & 501 \\
\hline $\mathrm{Rb}$ & 224 & 83 & 103 & 53 \\
\hline $\mathrm{Sr}$ & 53 & 147 & 235 & 127 \\
\hline $\mathrm{Zr}$ & 240 & 198 & 172 & 167 \\
\hline $\mathrm{F}$ & 8500 & 1550 & 880 & 780 \\
\hline $\mathrm{X}_{\mathrm{Mg}}\left(\mathrm{Fe}^{2+}\right)$ & 0.75 & 0.74 & 0.65 & 0.47 \\
\hline
\end{tabular}

SprGr-Sapphirine-bearing granulite; La-Layer; D I-Domain I; D II-Domain II; Domain III; Charno-Charnockite; $\mathrm{X}_{\mathrm{Mg}}=(\mathrm{MgO} / \mathrm{MgO}+\mathrm{FeO})_{\text {Molar }}$.
Table 10

Solution models and end members used for pseudosections

\begin{tabular}{lll}
\hline Solution model & Independent end members & Reference \\
\hline Spr(KWP) & spr4, fspr & Kelsey et al. (2004) \\
Spl(HP) & spl, herc & Holland and Powell (1998) \\
Bt(HP) & ann, phl, sdph, east & Holland and Powell (1998) \\
Grt(HP) & py, alm, gross & Holland and Powell (1998) \\
Opx(HP) & en, fs, mgts & Holland and Powell (1998) \\
hCrd & crd, fcrd, hcrd & Holland and Powell (1998) \\
Melt(HP) & qtz8L, kspL, sill8L, fo8L, fa8L, H ${ }_{2} \mathrm{OL}$ & White et al. (2001) \\
\hline
\end{tabular}

See Perple'X07 documentation (www.perplex.ethz.ch) for solution models reference.

\subsection{UHT metamorphism and the development of compositional domains}

The presence of compositional domains and spatial disposition of the microstructures with respect to the margin of the sapphirinebearing granulite (Fig. 4a, b) suggests that reactions were driven by the infiltration of silicate melt from the charnockite, which induced an increase of the bulk silica content resulting in the transformation of spinel into sapphirine and ultimately into cordierite (Fig. 11c). The crystallization of spinel-cordierite symplectites in sillimanite-rich and garnet-rich domains is related to cooling and decompression during orogeny evolution (cf. Harley, 1989; White et al., 2002, 2007). The formation of $\mathrm{Opx}_{2}+\mathrm{Crd}$ symplectites at the expense of Al-rich $\mathrm{Opx}_{1}$ + Grt porphyroblasts (reaction 9) is also favoured by decompression (Hensen, 1988). Thus the significance of compositional domains in the sapphirine-bearing granulite would be the result of melt-rock interactions and the establishment of Si-chemical potential gradients between the charnockite and the silica-undersaturated granulite combined with $P-T$ changes.

\section{Conclusions}

The studied silica-undersaturated sapphirine-bearing granulite enclaves in charnockite outcrop indicate that UHT metamorphic conditions were locally achieved in the Salvador-Curaçá Belt at $P-T$ conditions of $7.0-8.0 \mathrm{kbar}$ and $900-950{ }^{\circ} \mathrm{C}$. The in-situ EMP monazite ages indicate that UHT metamorphism occurred during the 2.082.05 Ga (Rhyacian) Paleoproterozoic orogeny.

The enclaves show a strong chemical and mineralogical zoning from core to rim with the following features: $\mathrm{Spr}+\mathrm{Spl}_{1}$ in the core, relicts of Sill porphyroblasts and $\mathrm{Crd}-\mathrm{Spl}_{2}-\mathrm{Mag}$ symplectites between core and margin, and relicts of Grt porphyroblasts breakdown into Crd-Opx 2 symplectites and Qtz-Crd+Qtz- $\mathrm{Bt}_{2}+\mathrm{Qtz}_{-}-\mathrm{Bt}_{2}$ symplectites at margin. This organisation reflects an increase of bulk $\mathrm{SiO}_{2}$ content from the core to the margins due to silica diffusion as a response of the establishment of chemical potential gradients in Si between protoenclave minerals and charnockite magma intrusion. The growth of sapphirine, spinel-cordierite and orthopyroxene-cordierite symplectites were favoured in the lowest $\mathrm{Si}$ domains furthest from the charnockite contact. In contrast, more silica-rich minerals such as garnet and quartz-bearing cordierite and biotite symplectites developed at or close to the contact with the charnockite. The calculated pseudosections also suggest that cordierite-host symplectites were formed during cooling and decompression of the orogenic evolution. This Paleoproterozoic UHT metamorphism represents one of the main processes of São Francisco Craton amalgamation and can be related to other UHT metamorphic events that occurred during Columbia supercontinent assembly.

\section{Acknowledgments}

We thank R. Moraes and D. Kelsey for their constructive reviews and suggestions to improve the manuscript. We thank M. Veschambre for providing the microprobe facilities during C.M.M. Leite's stay at the 

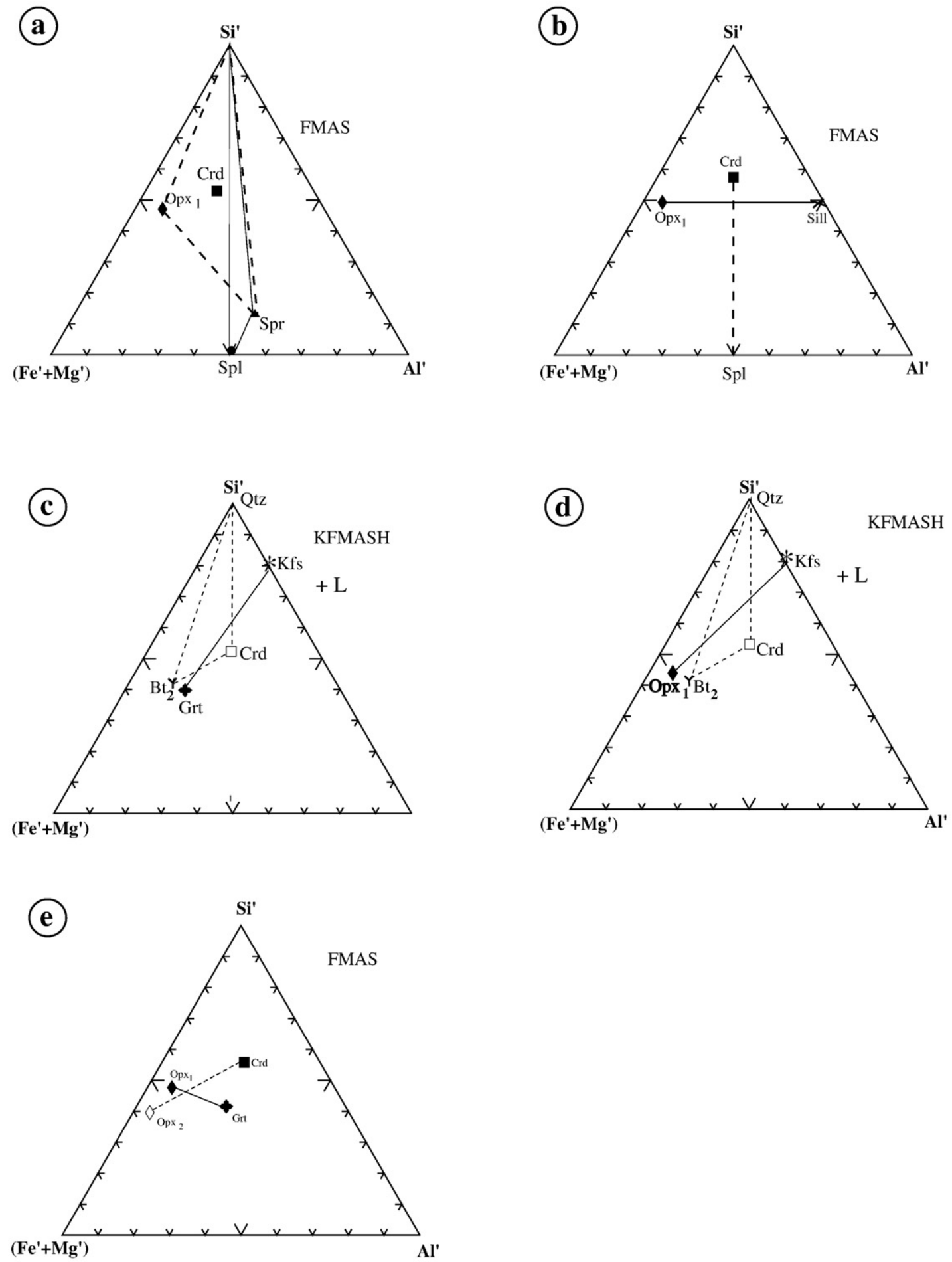

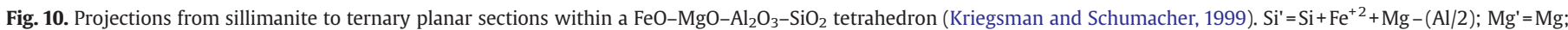
$\mathrm{Fe}^{\prime}=\mathrm{Fe}^{+2}$ and $\mathrm{Al}^{\prime}=\left(\mathrm{Al}+\mathrm{Fe}^{+3}+\mathrm{Cr}^{+3}\right) / 2$, all of them in a.p.f.u, in FMAS (a, b, e) and KFMASH (c) systems. The diagrams show inferred reactions from the observed microstructures.

Department de Géologie of Université Blaise Pascal and I. McReath for his help in improving the English. We also thank reviews for the journal by $\operatorname{Dr} \mathrm{T}$. Tsunogae (University Tsukuba, Japan) and an anonymous reviewer that led to considerable improvements of the manuscript. C.M.M. Leite thanks the Companhia Baiana de Pesquisa Mineral for the logistic support during fieldwork, and CAPES, Brazil for his doctoral fellowship (BEX 0482/99-4).

\section{References}

Ackermand, D., Herd, R.K., Reinhardt, M., Windley, B.F., 1987. Sapphirine parageneses from the Caraiba complex, Bahia, Brazil: the influence of $\mathrm{Fe}^{+2}-\mathrm{Fe}^{+3}$ distributions on the stability of sapphirine in natural assemblages. Journal of Metamorphic Geology 5, 323-339.

Almeida, F.F.M., 1977. O Cráton do São Francisco. Revista Brasileira de Geociências 7, 349-364. 
a $\mathrm{SiO} 2: \mathrm{Al} 2 \mathrm{O} 3: \mathrm{FeO}: \mathrm{MgO}: \mathrm{K} 2 \mathrm{O}: \mathrm{H} 2 \mathrm{O}$ $45.53: 14.44: 7.46: 22.73: 4.51: 6.33(\mathrm{~mol} \%)$

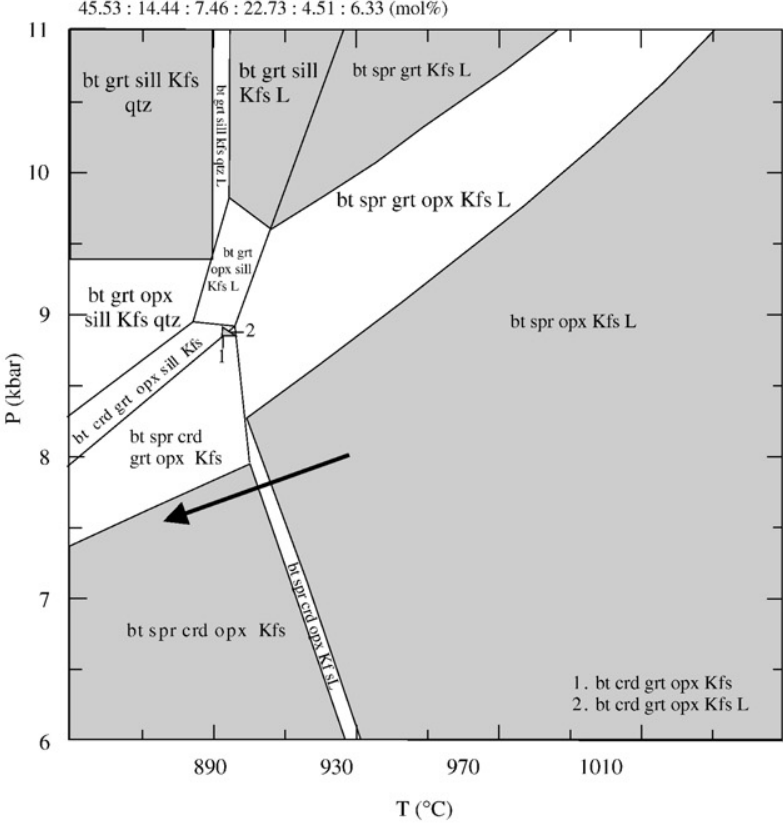

D $\mathrm{SiO} 2: \mathrm{Al} 2 \mathrm{O} 3: \mathrm{FeO}: \mathrm{MgO}: \mathrm{K} 2 \mathrm{O}: \mathrm{H} 2 \mathrm{O}$ $66.15: 10.33: 5.37: 8.65: 3.02: 6.48(\mathrm{~mol} \%)$

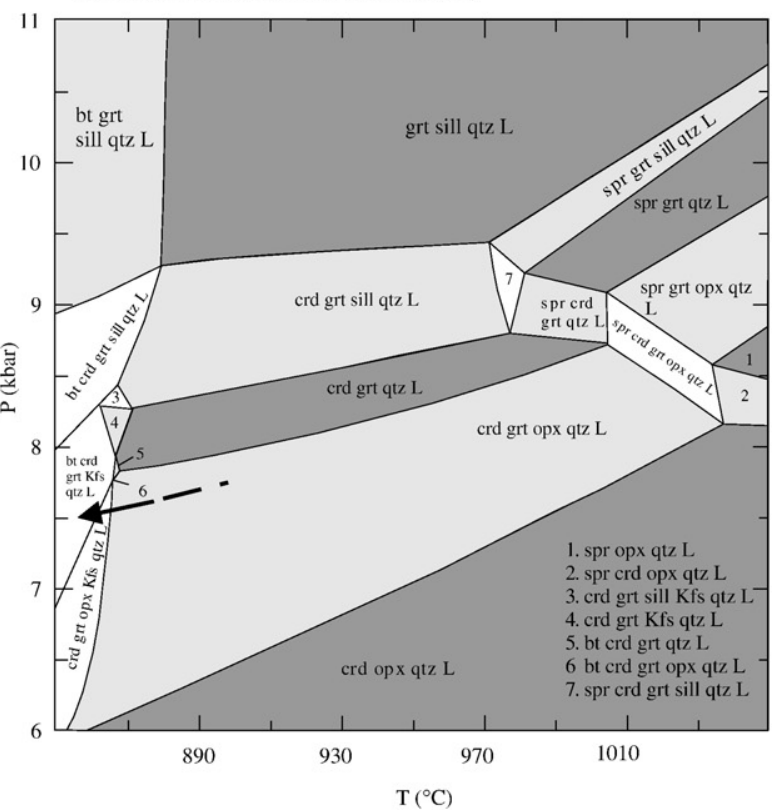

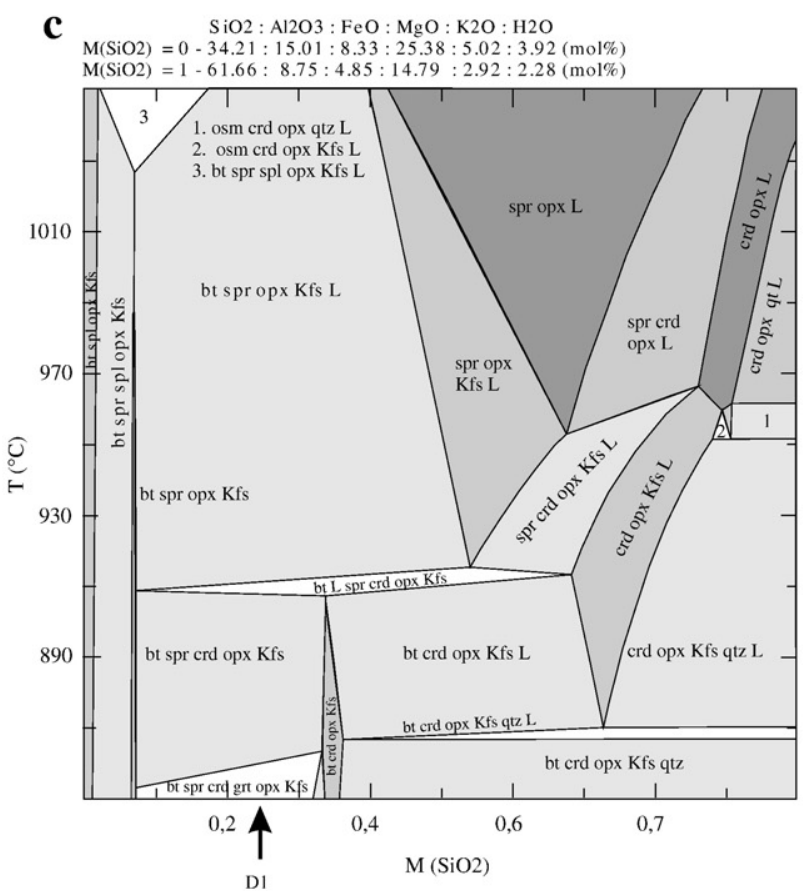

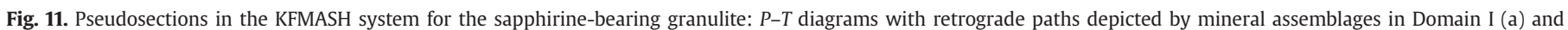
Domain III (b); and (c) $\mathrm{T}-\mathrm{M}\left(\mathrm{SiO}_{2}\right)$ at 8.0 kbar for Domain I depicting the influence of increasing $\mathrm{SiO}_{2}$ for sapphirine and cordierite crystallizations.

Baba, S., 1999a. Sapphirine-bearing orthopyroxene-kyanite/sillimanite granulites from South Harris, NW Scotland: evidence for Proterozoic UHT conditions in the Lewisian. Contributions to Mineralogy and Petrology 136, 33-47.

Baba, S., 1999b. Two stages of sapphirine formation during prograde and retrograde metamorphism in the Paleoproterozoic Lewisian complex in South Harris, NW Scotland. Journal of Petrology 44, 329-354.

Barbosa, J.S.F., Sabaté, P., 2002. Geological features and the Paleoproterozoic collision of four Archean crustal segments of the São Francisco Craton, Bahia, Brazil. A synthesis. Anais da Academia Brasileira de Ciências 74, 343-359.

Barbosa, J.S.F., Sabaté, P., 2004. Archean and Paleoproterozoic crust of the São Francisco Craton, Bahia, Brazil: geodynamic features. Precambrian Research 133, 1-27.

Barbosa, J.S.F., Nicollet, C., Leite, C., Kienast, J.R., Fuck, R.A., Macedo, E.P., 2006. Hercynitequartz-bearing granulites from Brejões Dome area, Jequié Block, Bahia, Brazil: influence of charnockite intrusion on granulite facies metamorphism. Lithos 92, 537-556.

Bohlen, S.R., Essene, E.J., 1977. Feldspar and oxide thermometry of granulites in the Adirondack Highlands. Contributions to Mineralogy and Petrology 62, 153-169.

Braun, I., Montel, J.M., Nicollet, C., 1998. Electron microprobe dating of monazites from high-grade gneisses and pegmatites of the Kerala Khondalite Belt, southern India. Chemical Geology 146, 65-85.

Brown, M., 2002. Retrograde processes in migmatites and granulites revisited. Journal of Metamorphic Geology 20, 25-40.

Brown, M., 2006. Duality of thermal regimes is the distinctive characteristic of plate tectonics since the Neoarchean. Geology 34, 961-964.

Brown, M., 2007. Metamorphic conditions in orogenic belts: a record of secular change. International Geology Review 49, 193-234. 
Table 11

Core compositions of garnet and orthopyroxene ${ }_{1}$ used for $P$ and $T$ calculations for samples 155C5 (Domain III of sapphirine-bearing granulite) and 155E (charnockite) using Grt-Opx thermometer Harley (1984) and Grt-Opx barometer of Harley and Green (1982), following the method of Pattison and Bégin (1994)

\begin{tabular}{lcc}
\hline Samples & $155 \mathrm{C} 5$ & $155 \mathrm{E}$ \\
\hline Garnet & $X_{\mathrm{mg}}\left(\mathrm{Fe}^{2+}\right)=0.451$ & $X_{\mathrm{mg}}\left(\mathrm{Fe}^{2+}\right)=0.481$ \\
Orthopyroxene $_{1}$ & $X_{\mathrm{mg}}\left(\mathrm{Fe}^{2+}\right)=0.665$ & $X_{\mathrm{mg}}\left(\mathrm{Fe}^{2+}\right)=0.723$ \\
& $y(\mathrm{opx})=0.132$ & $y(\mathrm{opx})=0.129$ \\
$T\left({ }^{\circ} \mathrm{C}\right)( \pm 40-60)$ & 950 & 945 \\
$P(\mathrm{kbar})( \pm 2.0)$ & 8.5 & 8.0 \\
\hline
\end{tabular}

Carrington, D.P., Harley, S.L., 1996. Cordierite as a monitor of fluid and melt $\mathrm{H}_{2} \mathrm{O}$ contents in the lower crust: an experimental calibration. Geology 24, 647-650.

Carvalho, M.J., Oliveira, E.P., 2003. Geologia do Tonalito Itareru, Bloco Serrinha, Bahia: uma intrusão sin-tectônica do início da colisão continental no segmento norte do Orógeno Itabuna-Salvador-Curaçá. Revista Brasileira de Geociências 33, 55-68.

Conolly, J.A.D., Petrini, K., 2002. An automated strategy for calculation of phase diagram sections and retrieval of rock properties as a function of physical conditions. Journal of Metamorphic Geology 20, 697-708.

Das, K., Dasgupta, S., Miura, H., 2001. Stability of osumilite coexisting with spinel solid solution in metapelitic granulites at high oxygen fugacity. American Mineralogist 86, 1423-1434.

Das, K., Dasgupta, S., Miura, H., 2003. An experimentally constrained petrogenetic grid in the silica-saturated portion of the system KFMASH at high temperatures and pressures. Journal of Petrology 44, 1055-1075.

Davies, J.H., von Blanckeburg, F., 1995. Slab breakoff: a model of lithosphere detachment and its tests in the magmatism and deformation of collisional orogens. Earth and Planetary Science Letters 129, 85-102.

Droop, G.T.R., Bucher-Nurminen, K., 1984. Reactions textures and metamorphic evolution of sapphirine-bearing granulites from the Gruf complex, Italian Central Alps. Journal of Petrology 5, 766-803.

Dunkley, D.J., Clarke, G.L., Harley, S.L. 1999. Diffusion metasomatism in silicaundersaturated sapphirine-bearing granulite from Rumdoole Peak, Framnes Mountains, East Antarctica. Contributions to Mineralogy and Petrology 134, 264-276.

Ellis, D.J., 1980. Osumilite-sapphirine-quartz granulites from Enderby Land, Antarctica: $P-T$ conditions of metamorphism, implications for garnet-cordierite equilibria and evolution of deep crust. Contributions to Mineralogy and Petrology 74, 201-210.

Farquhar, J., Chacko, T. Ellis, D.J. 1996. Preservation of oxygen isotope compositions in granulites from northwestern Canada and Enderby land, Antarctica: implications for high-temperature isotopic thermometry. Contributions to Mineralogy and Petrology 125, 213-224.

Fitzsimons, I.C.W., Harley, S.L., 1994. The influence of retrograde cation exchange on granulite $P-T$ estimates and a convergence technique for the recovery of peak metamorphic conditions. Journal of Petrology 35, 543-576.

Frost, B.R., Chacko, T., 1989. The granulite uncertainty principle: limitations on thermobarometry. Journal of Geology 97, 435-450.

Frost, B.R., Frost, C.D., 2008. On charnockites. Gondwana Research 13, 30-44.

Frost, B.R., Arculus, R.J., Barnes, C.G., Collins, W.J., Ellis, D.J., Frost, C.D., 2001. A geochemical classification of granitic rocks. Journal of Petrology 42, 2033-2048.

Fujimori, S., 1985. Sapphirine from Salvador, Bahia, Brazil: evidence for formation by exsolution. Revista Brasileira de Geociências 15, 18-24.

Fujimori, S., Allard, G.O., 1966. Ocorrência de safirina em Salvador, Bahia. Boletim da Sociedade Brasileira de Geociências 15, 67-81.

Goncalves, P., Nicollet, C., Lardeaux, J.M., 2003. Finite strain pattern in the Andriamena unit (north-central Madagascar): evidence for late Neoproterozoic-Cambrian thrusting during continental convergence. Precambrian Research 123, 135-157.

Goncalves, P., Nicollet, C., Montel, J.M., 2004. Petrology and in-situ U-Th-Pb monazite geochronology of ultrahigh-temperature metamorphism from Andriamena mafic unit, north-central Madagascar. Significance of a petrographical $P-T$ path in a polymetamorphic context. Journal of Petrology 45, 1923-1957.

Guidotti, C.V., 1984. Mica in metamorphic rocks. In: Bailey, S.W. (Ed.), Micas Mineralogical Society of America Reviews in Mineralogy, vol. 13, pp. 357-456.

Harley, S.L., 1984. An experimental study of the partitioning of $\mathrm{Fe}$ and $\mathrm{Mg}$ between garnet and orthopyroxene. Contributions to Mineralogy and Petrology 36, 359-373.

Harley, S.L., 1989. The origin of granulites: a metamorphic perspective. Geological Magazine 126, 215-247.

Harley, S.L., 1998. On the occurrence and characterization of ultrahigh-temperature crustal metamorphism. In: Treloar, P.J., O'Brien, P.J. (Eds.), What Drives Metamorphism and Metamorphic Reactions?, vol. 138. Geological Society of London Special Publications, London, UK, pp. 81-107.

Harley, S.L., Green, D.H., 1982. Garnet-orthopyroxene barometry for granulites and peridotites. Nature 300, 697-701.

Henry, D.J., Guidotti, C.V., 2002. Ti in biotite from metapelitic rocks: temperature effects, crystallochemical controls and petrological applications. American Mineralogist 87, 375-382.

Hensen, B.J., 1986. Theoretical phase relations involving cordierite and garnet revisited: the influence of oxygen fugacity on the stability of sapphirine and spinel in the system Mg-Fe-Al-Si-O. Contributions to Mineralogy and Petrology 92, 362-367.

Hensen, B.J., 1988. Chemical potential gradients and chemographic projections: application to sapphirine-bearing granulites from Kiranur and Ganguvarpatti,
Tamil Nadu. Evidence for rapid lift in part of the South Indian Shield? Neues Jahrbuch Fur Mineralogie. Abhandlungen 158, 193-210.

Hensen, B.J., Harley, S.L., 1990. Graphical analysis of $P-T-X$ in granulite facies metapelites. In: Ashworth, J.R., Brown, M. (Eds.), High-Temperature Metamorphism and Crustal Anatexis. Kluwer Academic Publishers, pp. 19-56.

Higgins, J.B., Ribbe, P.H., Herd, R.K., 1979. Sapphirine I. Crystal chemical contributions. Contributions to Mineralogy and Petrology, 68, 349-356.

Holland, T.J.B., Powell, R., 1998. An internally consistent thermodynamic data set for phases of petrological interest. Journal of Metamorphic Geology 16, 309-343.

Holland, T.J.B., Powell, R., 2001. Calculation of phase relations involving haplogranitic melts using an internally consistent thermodynamic data set. Journal of Petrology 42, 673-683.

Hollis, J.A., Harley, S.L., White, R.W., Clarke, G.L., 2006. Preservation of evidence for prograde metamorphism in ultrahigh-temperature, high-pressure kyanite-bearing granulites, South Harris, Scotland. Journal of Metamorphic Geology 24, 263-279.

Hou, G., Santosh, M., Qian, X., Lister, G.S., Li, J., in press. Configuration of the Late Paleoproterozoic supercontinent Columbia: Insights from radiating mafic dyke swarms. Gondwana Research 14. doi:10.1016/j.gr.2008.01.010.

Jessel, M.W., 1987. Grain-boundary migration microstructures in a naturally deformed quartzite. Journal of Structural Geology 9, 1007-1014.

Kelsey, D.E., 2008. On ultrahigh-temperature crustal metamorphism. Gondwana Research 13,1-29.

Kelsey, D.E., Powell, R., Wilson, C.J.L., Steele, D.A., 2003a. (Th+U)-Pb monazite ages from Al-Mg-rich metapelites, Rauer Group, east Antarctica. Contributions to Mineralogy and Petrology 146, 326-340.

Kelsey, D.E., White, R., Powell, R., 2003b. Orthopyroxene-sillimanite-quartz assemblages: distribution, petrology, quantitave $P-T-X$ constraints and $P-T$ paths. Journal of Metamorphic Geology 21, 439-453.

Kelsey, D.E., White, R., Holland, T.J.B., Powell, R., 2004. Calculated phase equilibria in $\mathrm{K}_{2} \mathrm{O}-\mathrm{FeO}-\mathrm{MgO}-\mathrm{Al}_{2} \mathrm{O}_{3}-\mathrm{SiO}_{2}-\mathrm{H}_{2} \mathrm{O}$ for sapphirine-quartz-bearing mineral assemblages. Journal of Metamorphic Geology 22, 559-578.

Kelsey, D.E., White, R., Powell, R., 2005. Calculated phase equilibria in $\mathrm{K}_{2} \mathrm{O}-\mathrm{FeO}-\mathrm{MgO}-$ $\mathrm{Al}_{2} \mathrm{O}_{3}-\mathrm{SiO}_{2}-\mathrm{H}_{2} \mathrm{O}$ for silica-undersaturated sapphirine-bearing mineral assemblages. Journal of Metamorphic Geology 23, 217-239.

Kosin, M., Melo, R.C., Souza, J.D., Oliveira, E.P., Carvalho, M.J., Leite, C.M.M., 2003. Geologia do segmento norte do Orógeno Itabuna-Salvador-Curaçá. Revista Brasileira de Geociências 33, 15-26.

Kretz, R., 1983. Symbols for rock-forming minerals. American Mineralogist 68, 277-279 Kriegsman, L.M., 2001. Partial melting, partial melting extraction and partial back reaction in anatectic migmatites. Lithos 56, 75-96.

\section{Table 12}

Representative monazite analyses (oxides in wt.\%) in sapphirine-bearing granulite (155) and charnockite (155E)

\begin{tabular}{|c|c|c|c|c|c|c|c|c|}
\hline $\begin{array}{l}\text { Sample/ } \\
\text { position }\end{array}$ & $155-2$ & $155-22$ & $155-1$ & $155-11$ & $155 \mathrm{E}-9$ & $155 \mathrm{E}-12$ & $155 \mathrm{E}-13$ & $155 \mathrm{E}-1$ \\
\hline $\mathrm{UO}_{2}$ & 0.54 & 0.77 & 0.95 & 1.18 & 0.54 & 0.88 & 0.67 & 0.11 \\
\hline $\mathrm{PbO}$ & 0.99 & 0.85 & 1.32 & 1.26 & 0.52 & 0.63 & 0.51 & 0.45 \\
\hline $\mathrm{ThO}_{2}$ & 8.63 & 6.46 & 10.67 & 9.06 & 3.50 & 3.05 & 2.68 & 4.50 \\
\hline $\mathrm{aO}$ & 1.93 & 1.96 & 1.99 & 2.58 & 1.33 & 1.35 & 1.26 & 1.76 \\
\hline${ }_{2} \mathrm{O}_{5}$ & 27.01 & 29.16 & 25.76 & 29.12 & 29.95 & 30.32 & 30.23 & 29.54 \\
\hline${ }_{2} \mathrm{O}_{3}$ & 1.94 & 2.66 & 1.16 & 3.21 & 2.44 & 1.59 & 1.45 & 0.54 \\
\hline $\mathrm{O}_{2}$ & 1.43 & 0.65 & 2.05 & 0.51 & 0.22 & 0.09 & 0.13 & 0.42 \\
\hline $\mathrm{La}_{2} \mathrm{O}_{3}$ & 14.94 & 15.29 & 13.21 & 13.63 & 15.34 & 16.13 & 16.29 & 15.44 \\
\hline $\mathrm{Ce}_{2} \mathrm{O}_{3}$ & 27.51 & 27.34 & 27.31 & 24.45 & 29.52 & 30.03 & 30.68 & 30.20 \\
\hline $\mathrm{Pr}_{2} \mathrm{O}_{3}$ & 2.46 & 2.24 & 2.54 & 2.06 & 2.66 & 2.71 & 2.74 & 2.89 \\
\hline $\mathrm{Nd}_{2} \mathrm{O}_{3}$ & 8.91 & 8.37 & 8.99 & 7.92 & 10.44 & 9.76 & 10.23 & 11.17 \\
\hline $\mathrm{Sm}_{2} \mathrm{O}_{3}$ & 1.14 & 1.22 & 1.28 & 1.18 & 1.62 & 1.34 & 1.41 & 1.48 \\
\hline $\mathrm{d}_{2} \mathrm{O}_{3}$ & 1.02 & 1.23 & 1.04 & 1.21 & 1.12 & 0.99 & 0.90 & 0.96 \\
\hline Total & 98.45 & 98.20 & 98.27 & 97.37 & 99.20 & 98.87 & 99.18 & 99.43 \\
\hline $\mathrm{P}$ & .764 & 3.897 & 3.656 & 3.919 & 3.966 & 3.986 & 3.980 & 3.934 \\
\hline $\mathrm{Si}$ & .236 & 0.103 & 0.344 & 0.081 & 0.034 & 0.014 & 0.020 & 0.06 \\
\hline La & 0.907 & 0.890 & 0.817 & 0.799 & 0.885 & 0.924 & 0.934 & 0.89 \\
\hline $\mathrm{Ce}$ & 1.658 & 1.580 & 1.676 & 1.423 & 1.690 & 1.707 & 1.747 & 1.73 \\
\hline $\operatorname{Pr}$ & 0.148 & 0.129 & 0.155 & 0.119 & 0.152 & 0.153 & 0.155 & 0.165 \\
\hline Nd & 0.524 & 0.472 & 0.538 & 0.450 & 0.583 & 0.541 & 0.568 & 0.62 \\
\hline $\mathrm{Sm}$ & .065 & 0.066 & 0.074 & 0.065 & 0.087 & 0.072 & 0.076 & 0.08 \\
\hline Gd & 0.056 & 0.064 & 0.058 & 0.064 & 0.058 & 0.051 & 0.046 & 0.05 \\
\hline Y & 0.170 & 0.223 & 0.103 & 0.272 & 0.203 & 0.131 & 0.120 & 0.04 \\
\hline ¿REE & 3.527 & 3.425 & 3.422 & 3.191 & 3.658 & 3.580 & 3.646 & 3.60 \\
\hline U & 0.020 & 0.027 & 0.035 & 0.042 & 0.019 & 0.030 & 0.023 & 0.004 \\
\hline Th & 0.323 & 0.232 & 0.407 & 0.328 & 0.125 & 0.108 & 0.095 & 0.161 \\
\hline $\mathrm{Pb}$ & 0.044 & 0.036 & 0.059 & 0.054 & 0.022 & 0.026 & 0.021 & 0.019 \\
\hline $\mathrm{Pb} /(\mathrm{Th}+\mathrm{U})$ & 0.128 & 0.139 & 0.133 & 0.146 & 0.153 & 0.188 & 0.178 & 0.115 \\
\hline $\mathrm{Ca}$ & 0.340 & 0.332 & 0.357 & 0.439 & 0.223 & 0.225 & 0.210 & 0.297 \\
\hline
\end{tabular}

Structural formulae (a.p.f.u.) based on eight cations assuming $\mathrm{P}+\mathrm{Si}=4$ (Montel et al., 1996). 

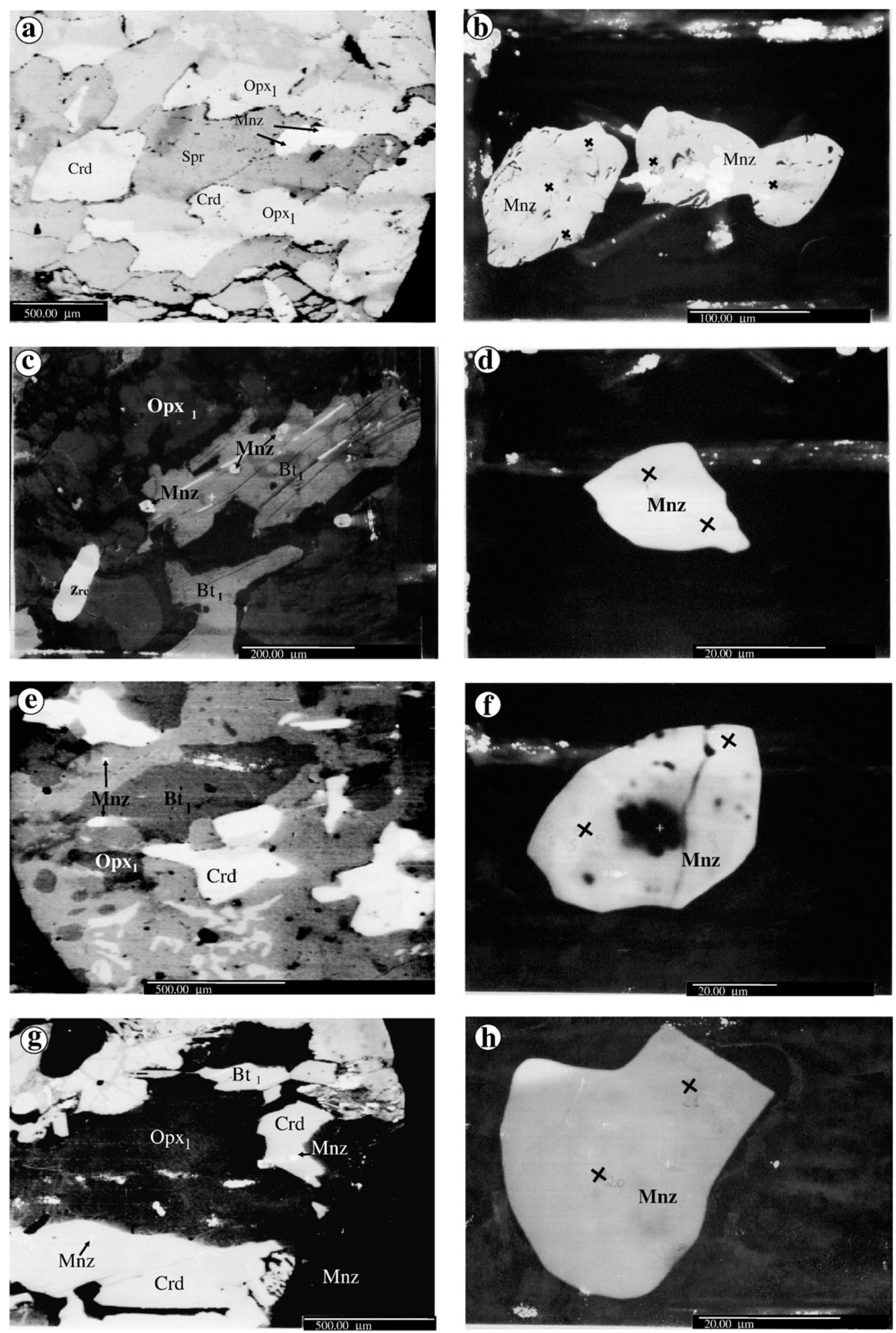

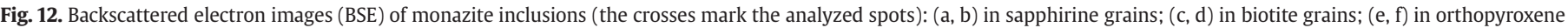
grains, $(\mathrm{g}, \mathrm{h})$ in cordierite grains.

Kriegsman, L.M., Hensen, B.J., 1998. Back reaction between restite and melt: implications for geothermobarometry and pressure-temperature paths. Geology 26, 1111-1114 Kriegsman, L.M., Schumacher, J.C., 1999. Petrology of sapphirine-bearing and associated granulites from Central Sri Lanka. Journal of Petrology 40, 1211-1239.

Ledru, P., Johan, V., Milési, J.P., Tegyey, M., 1994. Markers of the last stages of the Palaeoproterozoic collision: evidence for a 2 Ga continent involving circum-South Atlantic provinces. Precambrian Research 69, 169-191.
Ledru, P., Milési, J.P., Johan, V., Sabaté, P., Maluski, H., 1997. Foreland basins and goldbearing conglomerates: a new model for the Jacobina Basin (São Francisco Province, Brazil). Precambrian Research 86, 155-176.

Leite, C.M.M., 2002. A Evolução Geodinâmica da Orogênese Paleoproterozóica nas regiões de Capim Grosso-Jacobina e Pintadas-Mundo Novo (Bahia-Brasil): Metamorfismo, Anatexia e Tectônica. PhD. thesis, Universidade Federal da Bahia. 

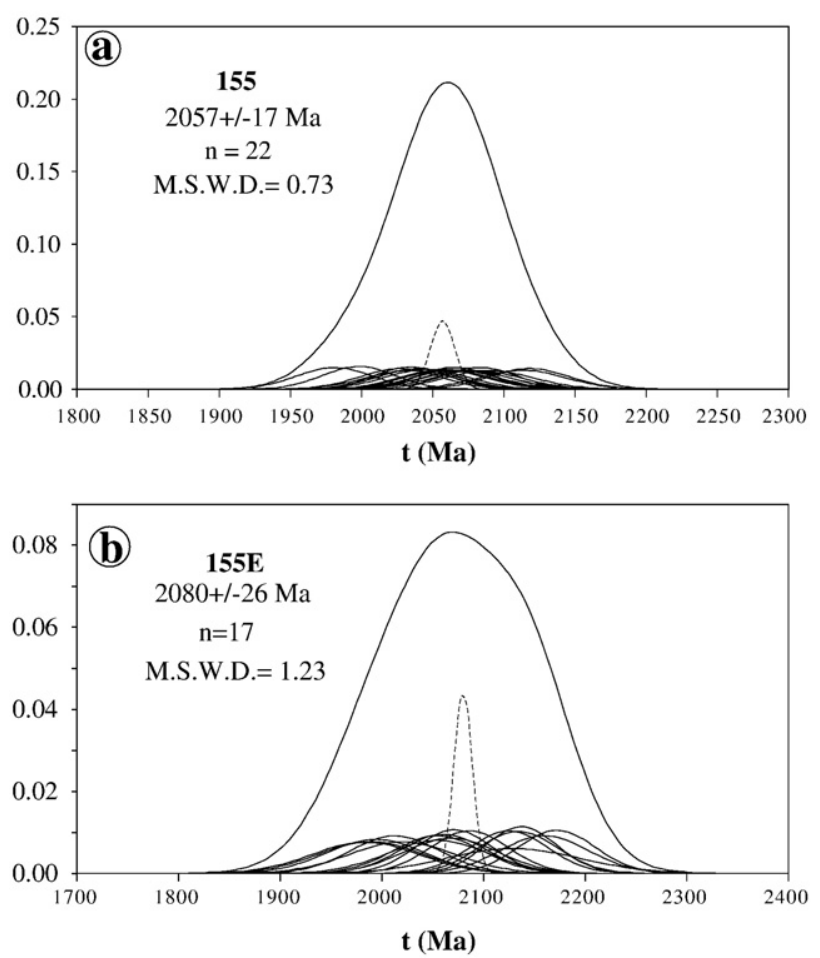

Fig. 13. Weighted histogram representations of monazite data for (a) sapphirinebearing granulite and (b) charnockite. Each measurement is represented by its probability density function (bell-shaped curve). Each thick curve is the sum of all individual ages (bell curves). The dashed curves are the statistically derived age populations. There is no unit for the vertical scale.

Mahan, K.H., Goncalves, P., Williams, M.L., Jercinovic, M.J., 2006. Dating metamorphic reactions and fluid flow: application to exhumation of high- $P$ granulites in a crustal-scale shear zone, western Canadian Shield. Journal of Metamorphic Geology 24, 193-217.

Mascarenhas, J.F., Silva, E.F.A., 1994. Greenstone Belt de Mundo Novo (Bahia): caracterização e implicações metalogenéticas no Craton do São Francisco. Série Arquivos Abertos, vol. 7. CBPM, Salvador, Brazil. 32 pp.

Mascarenhas, J.F., Ledru, P., Souza, S.L., Conceição Filho, V.M., Melo, L.F.A., Lorenzo, C.L., Milési, J.P., 1998. Geologia e recursos minerais do Grupo Jacobina e da parte sul do Greenstone Belt de Mundo Novo. Série Arquivos Abertos, vol. 13. CBPM, Salvador, Brazil. 58 pp.

Melo, R.C., Loureiro, H.S.C., Pereira, L.H.M., 1995. Programa Levantamentos Geológicos Básicos do Brasil, CPRM. Serrinha, Folha SC-24-Y-D, escala 1: 250.000, 80 pp.

Montel, J.M., Foret, S., Veschambre, M., Nicollet, C., Provost, A., 1996. Electron microprobe dating of monazite. Chemical Geology 131, 37-53.

Moraes, R., Brown, M., Fuck, R.A., Camargo, M.A., Lima, T.M., 2002. Characterization and $P-T$ evolution of melt-bearing ultrahigh-temperature granulites: an example from the Anápolis-Ituaçu Complex of the Brasília Fold Belt, Brazil. Journal of Petrology 43, 1673-1705.

Mougeot, R., 1996. Ëtude de la limite Archéen-Protérozoique et des mineralisations Au, \pm U associées: Exemples des régions de Jacobina (Etat de Bahia, Brésil) et de Carajás (Etat de Pará, Brésil). PhD. thesis. Université Montepellier II.

Mouri, H., Guiraud, M., Hensen, B.J., 1996. Petrology of phlogopite-sapphirine-bearing $\mathrm{Al}-\mathrm{Mg}$ granulites from Ihouhaouene, In Ouzzal, Hoggar, Algeria: an example of phlogopite stability at high temperature. Journal of Metamorphic Geology 14, 725-738.

Oliveira, E.P., Windley, B.F., McNaughton, N.J., Pimentel, M., Fletcher, I.R., 2004. Contrasting copper and chromium metallogenic evolution of terranes in the Paleoproterozoic Itabuna-Salvador-Curaçá orogen, São Francisco craton, Brazil: new zircon (SHRIMP) and Sm-Nd (model) ages and their significance for orogenparallel escape tectonics. Precambrian Research 128, 143-165.

Pattison, D.R.M., Bégin, N.J., 1994. Zoning patterns in orthopyroxene and garnet in granulites: implications for geothermometry. Journal of Metamorphic Geology 12, 387-410.

Pattison, D.R.M., Chacko, T., Farquhar, J., McFarlane, C.R.M., 2003. Temperatures of granulite-facies metamorphism: constraints from experimental phase equilibria and thermobarometry corrected for retrograde exchange. Journal of Petrology 44, 867-900.

Peucat, J.J., Mascarenhas, J.F., Barbosa, J.S.F., Souza, S.L., Marinho, M.M., Fanning, C.M., Leite, C.M.M., 2002. 3.3 Ga SHRIMP U-Pb zircon age of a felsic metavolcanic rock from the Mundo Novo Greenstone Belt in the São Francisco Craton, Bahia (NE Brazil). Journal of South American of Earth Science 15, 363-373.

Rogers, J.J.W., 1996. A history of continents in the past three billion years. Journal of Geology 104, 91-107.

Rogers, J.J.W., Santosh, M., 2002. Configuration of Columbia, a Mesoproterozoic Supercontinent. Gondwana Research 5, 5-22.

Sabaté, P., 1996. Estruturas e tectônica do embasamento Arqueano/Proterozóico Inferior do Estado da Bahia. In: Barbosa, J.S.F., Dominguez, J.M.L. (Eds.), Mapa Geológico do Estado da Bahia, Texto Explicativo Escala 1: 1.000.000, SICM/SGM, Salvador, Brazil, pp. 200-226.

Sabaté, P., Cuney, M., Vidal, Ph., 1990. Expressão estrutural e plutônica de uma colisão transamazônica N-S no Cráton do São Francisco (Bahia-Brasil). $36^{\circ}$ Congresso Brasileiro de Geologia Boletim Resumos. SBG, Natal, Brazil, p. 323.

Sampaio, A.R., 1995. Programa Levantamentos Geológicos Básicos do Brasil, DNPM/ CPRM. Jacobina, Folha SC-24-Y-C, escala 1: 250.000, 70 pp.

Santosh, M., Omori, S., 2008a. $\mathrm{CO}_{2}$ flushing: a plate tectonic perspective. Gondwana Research 13, 86-102.

Santosh, M., Omori, S., 2008b. $\mathrm{CO}_{2}$ windows from mantle to atmosphere: models on ultrahigh-temperature metamorphism and speculations on the link with melting of snowball Earth. Gondwana Research 14, 82-96.

Santosh, M., Yokoyama, K., Biju-Sekhar, S., Rogers, J.J.W., 2003. Multiple tectonothermal events in the granulite blocks of southern India revealed from EPMA dating: implications on the history of supercontinents. Gondwana Research 6, 29-63.

Santosh, M., Collins, A.S., Tamashiro, I., Koshimoto, S., Tsutsumi, Y., Yokoyama, K., 2006. The timing of ultrahigh-temperature metamorphism in Southern India: $\mathrm{U}-\mathrm{Th}-\mathrm{Pb}$ electron microprobe ages from zircon and monazite in sapphirine-bearing granulites. Gondwana Research 10, 128-155.

Santosh, M., Tsunogae, T., Li, J.H., Liu, S.J., 2007. Discovery of sapphirine-bearing Mg-Al granulites in the North China Craton: implications for Paleoproterozoic ultrahigh temperature metamorphism. Gondwana Research 11, 263-285.

Sarkar, S., Dasgupta, S., Fukuoka, M., 2003. Petrological evolution of a suite of spine granulites from Vizianagram, Eastern Ghats Belt, India, and genesis of sapphirinebearing granulite. Journal of Metamorphic Geology 21, 899-913.

Sengupta, P., Dasgupta, S., Bhattacharya, P.K., Fukuoka, M., Chakraborkti, S., Bhowmick S., 1990. Petrotectonic imprints in sapphirine granulites from Anantagiri, Eastern Ghats, India and their implications. Journal of Petrology 31, 971-996.

Silva, L.C., McNaughton, N.J., Melo, R.C., Fletcher, I.R., 1997. U-Pb SHRIMP ages in the ItabunaCaraíba TTG high-grade complex: the first window beyond the Paleoproterozoic overprint of the eastern Jequié Craton, NE Brazil. II ISGAM - International Symposium on Granites and Associated Mineralisations. SBG, Salvador, Brazil, pp. 282-283.

Silva, L.C., Armstrong, R., Delgado, I.M., Pimentel, M., Arcanjo, J.B., Melo, R.C., Teixeira, L.R., Jost, H., Cardoso Filho, J.M., Pereira, L.H.M., 2002. Reavaliação da evolução geológica em terrenos Précambrianos brasileiros com base em novos dados U-Pb SHRIMP, Parte I: Limite centro-oriental do Cráton do São Francisco. Revista Brasileira de Geociências 33, $501-522$.

Stevens, G., Clemens, J.C., 1993. Fluid absent melting and the roles of fluids in the lithosphere: a slanted summary. Chemical Geology 108, 1-17.

Stormer Jr., J.C., 1973. The composition of sapphirine from Salvador, Bahia, and conditions of its formation. Revista Brasileira de Geociências 3, 192-200.

Teixeira, L.R., 1997. O Complexo Caraíba e a Suíte São José do Jacuípe no Cinturão Salvador-Curaçá (Bahia, Brasil): petrologia, geoquímica e potencial metalogenético. PhD. thesis, Universidade Federal da Bahia.

Teixeira, W., Sabaté, P., Barbosa, J.S.F., Noce, C.M., Carneiro, M.A., 2000. Archean and Paleoproterozoic Tectonic evolution of the São Francisco Craton, Brazil. In: Cordani, U.G., Milani, E.J., Thomas Filho, A., Campos, D.A. (Eds.), Tectonic Evolution of South America. 31st International Geological Congress, Rio de Janeiro, Brazil, pp. 101-137.

Teixeira, J.B.G., Misi, A., Silva, M.G., 2007. Supercontinent evolution and the Proterozoic metallogeny of South America. Gondwana Research 11, 346-361.

Turnock, A.C., Eugster, H.P., 1962. Fe-Al Oxides: phase relationships below $1000{ }^{\circ} \mathrm{C}$ Journal of Petrology 3, 533-565.

Ulmer, P., 1993. Calculation of various Mineral- Norms, Program NORM-(Version 4.0)

Viertel, H.U., Seifert, F., 1981. Thermal stability of defect spinels in the system $\mathrm{MgAl}_{2} \mathrm{O}_{4}$ $\mathrm{Al}_{2} \mathrm{O}_{3}$. Neues Jahrbuch Fur Mineralogie. Abhandlungen 140, 89-101.

von Blanckeburg, F., Davies, J.H., 1995. Slab break off: a model for syncollisional magmatism and tectonics in the Alps. Tectonics 14, 120-131.

White, R.W., Powell, R., 2002. Melt loss and the preservation of granulite facies assemblages. Journal of Metamorphic Geology 20, 621-632.

White, R.W., Powell, R., Holland, T.J.B., 2001. Calculation of partial melting equilibria in the system $\mathrm{Na}_{2} \mathrm{O}-\mathrm{K}_{2} \mathrm{O}-\mathrm{FeO}-\mathrm{MgO}-\mathrm{Al}_{2} \mathrm{O}_{3}-\mathrm{SiO}_{2}-\mathrm{H}_{2} \mathrm{O}$ (NCKFMASH). Journal of Metamorphic Geology 19, 139-153.

White, R.W., Powell, R., Clarke, G.L., 2002. The interpretation of reaction textures in Ferich metapelitic granulites of the Musgrave Block, central Australia: constraints from mineral equilibria calculations in the system $\mathrm{K}_{2} \mathrm{O}-\mathrm{FeO}-\mathrm{MgO}-\mathrm{Al}_{2} \mathrm{O}_{3}-\mathrm{SiO}_{2}-$ $\mathrm{H}_{2} \mathrm{O}-\mathrm{TiO}_{2}-\mathrm{Fe}_{2} \mathrm{O}_{3}$. Journal of Metamorphic Geology 20, 41-55.

White, R.W., Powell, R., Holland, T.J.B., 2007. Progress relating to calculation of partia melting equilibria for metapelites. Journal of Metamorphic Geology 25, 511-527.

Zhao, G.C., Cawood, P.A., Wilde, S.A., Sun, M., 2002. Review of global 2.1-1.8 orogens: implications for a pre-Rodinia supercontinent. Earth-Science Reviews 59, 125-162.

Zhao, G.C., Sun, M., Wilde, S.A., Li, S., 2004. A Paleoproterozoic-Mesoproterozoic supercontinent: assembly, growth and break-up. Earth-Science Reviews 67, 91-123. 